\title{
Buying Stability: The Distributive Outcomes of Private Politics in the Bolivian Mining Industry ${ }^{1}$
}

\author{
Matthew Amengual \\ MIT \\ amengual@mit.edu
}

This version: 11/27/2017

Forthcoming: World Development

\begin{abstract}
:
Social movements and interest groups in developing countries increasingly challenge large firms to influence their behavior and make direct claims for redistribution of the gains from economic activity. In response to such private politics, firms seek to maintain political support in the localities in which they operate so that they can avoid conflict and secure access to resources. To secure local support and defuse opposition, some firms take actions that expand access to essential public goods, services, and economic opportunities, while others use targeted clientelistic benefits that reward only a few. What accounts for this variation? Answering this question is key to identifying the development consequences of private politics. This article explores this question through a study of multinational mining firms operating in Bolivia, drawing on qualitative data from interviews as well as an original household survey. It shows that the political structures and organization in the localities in which firms operate create distinct incentives for firms to distribute benefits in targeted or inclusive ways. This finding contributes to studies of the local politics of natural resources and firm responses to social contestation.
\end{abstract}

KEYWORDS: Private politics, social conflict, mining, extractives, Bolivia.

\footnotetext{
${ }^{1}$ The most important contribution to this paper was made by the actors in Bolivia, both community leaders and managers, who agreed to share information with me. Without their generosity in time and openness, this paper would not have been possible. I thank Renato Lima de Oliviera, Ignacio Puente, and Andrew Morales for their work as research assistants and Daniel Moreno and his team at Ciudadania for their support with the survey and follow-up presentations. The paper benefitted from feedback from audiences at seminars at Berkeley, Brown, Bocconi, Cornell, George Washington, Harvard, M.I.T., McGill, University of Pennsylvania, and REPAL. More people provided comments on previous drafts than I can possibly thank; I am especially indebted to Moises Arce, Salo Coslovsky, Greg Distelhorst, Sinziana Dorubato, Tasha Fairfield, Paul Haslam, Alisha Holland, Maiah Jaskoski, Thomas Kochan, Vicky Murillo, Alison Post, Ben Ross Schneider, Jessica Steinberg, and Rebecca Wietz-Shapiro. Funding was provided by MIT Sloan and the J.H. and E.V. Wade Fund at MIT.
} 
Social movements and interest groups of a variety of types increasingly challenge large firms to influence their activities and make direct claims for redistribution of the gains from economic activity (Vogel 2008). In response to such private politics, firms seek to maintain political support in the localities in which they operate so that they can avoid conflict and gain access to the resources they require. To secure support and defuse opposition, some firms take actions that expand access to essential public goods, services, and economic opportunities, while others use targeted clientelistic benefits that reward only a few. Thus, private politics can have divergent distributive consequences that contribute to local development outcomes. What accounts for this variation?

This article explores the distributive consequences of private politics through an analysis of four multinational mining firms operating in Bolivia. Natural resources make a particularly good context for inquiry. On the one hand, localities in which mining firms operate experience negative externalities and struggle to capture the gains from natural resource extraction. On the other hand, there have been extensive conflicts between social actors and mining firms (Bebbington et. al. 2008, Arce 2014; Jaskoski 2014; Haslam \& Tanimoune 2016; Paredes 2016; Dargent et. al. 2017). Exposed due to their large capital investments and need to access resources, mining firms have powerful incentives to distribute economic resources in ways that might prevent disruptive conflicts (Perla 2012; Henisz et al 2013; Franks et. al. 2014; Costanza 2016). Yet the dominant approach to analyzing distributive politics of natural resource still focuses mainly on states as the only actor that converts rents from extraction into public goods and social services, either ignoring firms as distributors of rents or contending that the actions of firms are uniformly clientelistic (Frynas 2005; Arellano-Yanguas 2011a; Zarsky 2013). These studies suggest that firms either do not need to maintain local political support or that firms can 
gain support through clientelism and therefore do not have incentives to augment local access to public goods and social services. Does political support for mining firms depend upon factors beyond individual exchange, such as the quality of public goods and social services in the localities where they operate? Under what conditions do firms have incentives to undertake inclusive distribution in order to maintain a political climate in which they can operate?

Drawing on qualitative data gathered during fieldwork and an original survey of 1,425 people in four mining enclaves in Bolivia, I show that the state is not the only actor distributing rents from extractives; some firms respond to political demands by engaging in private distribution, which I define as the distribution of economic benefits by firms for political purposes. In addition, I uncover variation in the forms in which firms distribute benefits, with only some contributing to public goods and social services in a sustained way in the localities where they operate. My explanation for this variation hinges on the ways social organization and structures of the localities, or enclaves, in which the firms operate generate political incentives for firms to engage in targeted or inclusive distribution. When enclaves are fragmented in terms of the economic interests of the population and local social organizations, firms bargain with groups that constitute a small fraction of the population and, consequently, request targeted benefits. By contrast, when enclaves are cohesive, firms tend to bargain with groups that consider the interests of the entire enclave and, consequently, request public goods and shared benefits. In addition, only in cohesive enclaves does public opinion towards firms become linked to the quality of collective goods and social services in nearby communities. Thus, only in these cases do firms gain mass support by improving service quality broadly. In sum, I provide an account of the local politics of extractives that incorporates direct, private 
distribution. By doing so, I build a theory of who gets what from firms' efforts to generate political support in the face of social pressure in the localities where they operate.

\section{LOCAL NATURAL RESOURCES POLITICS}

A growing literature on private politics analyzes contestation between social actors and firms in the extractives industry. Studies have shown that a range of actors-for example, community, labor, environmental, and agricultural organizations - employ legal and contentious means to influence resource extraction. A recent study of Latin America found that more than one hundred large mines, one fifth of all those operating, faced contentious mobilizations that involved blockades, strikes, and, at times, violence (Haslam and Tanimoune 2016; on Africa, see Steinberg 2018). There has been a substantial debate over the causes of these conflicts, with theories pointing to various factors, including the negative externalities of extractives that threaten people's livelihoods, the unequal distribution of economic benefits, and the behavior of states (Bebbington et al 2008; Arce 2014; Jaskoski 2014; Ponce \& McClintock 2014; Haslam and Tanimoune 2016; Ozen \& Ozen 2016). These studies have also put forth theories to explain why particular social movements succeed in achieving their goals.

While debates over the causes of social mobilization and success of groups seeking to block the expansion of extraction continue, it is clear that firms have strong incentives to respond to social demands and prevent costly conflict, as studies show a direct relationship between profits and local support (Henisz et al 2013). One action firms take to gain political support is providing economic benefits, such as public goods and development assistance, for the localities where they operate (Markus 2012; Franks et al 2014). Studies have documented firms using this approach in a range of countries, including Guatemala (Costanza 2016), Malawi (Kamlongera 2013), Mozambique (Steinberg 2016), and Papua New Guinea (Banks 2013). Funds that firms 
allocate to such private distribution are substantial; for example, between 2008 and 2011, a set of forty Peruvian mining firms reported voluntary payments for local development totaling \$157 million per year (to put this into context, international development aid that flowed into Peru during this period was $\$ 395$ million annually). ${ }^{2}$

While the sums are large, the distributive effects of private politics have not been systematically studied —we know little about who gains what from contestation. Overall, there is skepticism that expenditures by firms can contribute to access to public goods and social services in areas affected by extractives industries. Researchers often claim that power asymmetries between firms and social groups are so extreme that firms have to do little to gain local support. Moreover, scholars contend that the political linkages between firms and individuals are built upon individual clientelistic exchange, rather than on firms' contributions to local development (Frynas 2005; Arellano-Yanguas 2011b; Zarsky 2013). Thus, if there are any improvements in public goods provision or social services due to extractives, they should come through state redistribution. Such a view is implicitly shared with a related strain of literature on the distributive consequences of natural resource industries that analyzes the state as the sole distributor (Robinson, Torvik, and Verdier 2006; Arellano-Yanguas 2011a; Caselli \& Michaels 2013). Combined, these studies suggest that people living in extractives enclaves solely access public goods and social services provided by states.

While still nascent in the literature, there have been attempts to describe or explain the different ways in which firms might distribute rents in response to social pressure. One set of accounts looks to the state to explain firm behavior. Some studies suggest that when states are less willing to support firms in the face of protest, firms are more likely to expend resources to

\footnotetext{
${ }^{2}$ Firm spending data EITI, aid data, IMF.
} 
maintain peace locally (Steinberg 2016). Others suggest that local governments play a key role by helping firms gain political support and by serving as an intermediary between the firm and society (Costanza 2016). Therefore, we might expect the position of governments, whether they seek to attract and retaining foreign capital, as well as the state's actions to achieve these goals, to influence the distribution of rents by firms. Another possibility is that governments implement policies that allow firms to displace the state by taking on basic developmental tasks. For instance, the right-leaning Peruvian government of Alan-Garcia created a program to stimulate voluntary contributions of mining firms (Arrellano-Yanguas 2011b), while the subsequent more left-leaning Humala administration ended the program to more fully insert the state into the redistribution process. As private provision of social services might displace the state (Jones Luong 2014), left-leaning governments may avoid such actions by firms.

An alternative set of accounts looks not to the state but to international norms that can induce firms to contribute to local economic development. For example, Jones Luong and Weinthal (2010) argue that some extractive firms have a greater "commitment" to responsibility and, as a result, provide public goods that influence local development. Researchers have pointed to firm participation in international programs and industry organizations, such as the International Council on Mining and Metals (ICMM), as an indication that a firm abides by standards (Dashwood 2012). Others have predicted that small firms, sometimes called junior and mid-tier firms, are less constrained by global norms compared with senior firms (Dougherty 2011). Furthermore, firms with capital from China are often hypothesized to be unconstrained by global norms compared with multinationals headquartered in advanced industrial countries (Kotschwar 2011). These arguments predict that "responsible" firms - that is, those engaged with global norms - contribute to local development. 


\section{DISTRIBUTIVE CONSEQUENCES OF PRIVATE POLITICS}

In contrast with the accounts in the extant literature, I build a theory of differences in firms' local distribution of economic benefits around the incentives firms have to maintain political support in the areas in which they operate. I center the analysis on each firm's enclave, defined as the geographic area where production takes place that is highly influenced by a firm in terms of economic ties and exposure to negative externalities. To begin, I first conceptualize variation in private distribution by firms. At one extreme, which I label inclusive distribution, benefits are not targeted at a subgroup of individuals but are received by large swaths of the population. Such distribution is sustained throughout the life of the firm's operation. As enclaves have heterogeneous needs, I include both one-time transfers, such as the construction of drinking water infrastructure, and ongoing services, such as health care and education. Inclusive distribution can also include support to local development organizations, such as agricultural associations. It can be direct, with the firm acting as a provider, or through a non-state intermediary, with the firm contracting non-governmental organizations to provide benefits.

At another extreme, firms provide targeted benefits to a small, but politically important, subset of the population. The individuals who gain benefits may be core supporters of the firm, such as workers who defend the firm, or potent political challengers, such as factions who mobilize to (or threaten to) attack the firm. For their support or acquiescence, firms provide these groups with targeted benefits, such as cash payouts, small infrastructure projects, or opportunities to gain lucrative contracts from the firm. By definition, with targeted distribution, a minority gains while most are systematically excluded. Thus, compared with inclusive distribution, when there is targeted distribution a smaller portion of the people living in the firm's enclave gain benefits from the firm. Ultimately, targeted distribution may neutralize 
political challenges to firms, but it is unlikely to augment access to basic goods and services, or to contribute to local development. Instead, this form of distribution by private actors approximates what the literature on state distribution conceptualizes as clientelism (Kitschelt \& Wilkinson 2007).

Firms can engage in both inclusive and targeted distribution simultaneously. However, given that firms are profit motivated and budget constrained, they are forced to make tradeoffs between the two. Much of the literature on extractives politics that includes discussion of private distribution assumes that the targeted type always dominates. Indeed, private distribution is not, by definition, subject to constraints of formal institutions, and the localities that host extractives industries in developing countries tend to have many of the demand side characteristics, such as poverty, that are conducive to clientelism (Kitschelt \& Wilkinson 2007, Weitz-Shapiro 2014). Few, however, have sought to explain variation in private distribution: what factors push firms to engage in more inclusive or targeted distribution?

In a stylized manner, we can begin our analysis with a firm entering a new locality, either as a new operation or when taking ownership of an existing operation. Large firms tend to conform with international norms and, at least superficially, offer social benefits broadly in the local population. However, as a firm enters, it faces a variety of actors that make demands on the firm and can affect the firm's ability to operate. As the project develops, social structures and organizations evolve, with both firms and social actors seeking to reshape the local political arena by reinforcing or undermining existing structures. While firms are not completely passive, I assume that they are not in complete control of the political pressures that mount. Patterns of interaction form and managers have incentives to adjust the firm's distribution of benefits in ways that will resolve political demands on the firm or reduce the likelihood of future conflict. 
Variation in the social structures and organization of interests underpin distinct patterns of contestation. I classify localities in which firms operate (i.e. enclaves) as approximating two ideal types: fragmented and cohesive. Fragmented enclaves are those with competing economic groups that do not share membership in a functioning bridging social organization. Divisions vary by context, but the essential feature is that fragmentation is the presence of groups or factions that compete with one another to gain benefits from the firm. In some cases, key divides are between those who have economic ties to the firm and the rest of the population. For example, such a division can occur when there is a large, alternative economic sector in the immediate vicinity of the extractives project, such as agriculture, that competes with the firm for land or water (Arce 2014). As a result, a portion of the population gains from the firm (e.g. through employment), while outsiders are harmed, due either to exclusion from economic activities or to negative externalities. In other cases, enclaves are divided among communities or social groups. For instance, some people might be landowners who gain windfalls from the entry of the firm, while others are left out. By contrast, in cohesive enclaves, economic divisions are less pronounced due either to more uniform interests (e.g. an absence of competing economic activities) or social organizations that aggregate competing interests. For example, communal land ownership renders an enclave more cohesive than does private land ownership, as it diminishes economic divides between those who own valuable tracts of land and the rest of the population and creates a singular social organization to aggregate the interests of the entire community. Similarly, alliances between labor unions and community organizations underlie cohesion.

The structures and organization of enclaves affect firm-community interactions in two interrelated ways, triggering mechanisms that create incentives for either targeted or inclusive 
distribution. First, fragmentation and cohesion influence whether a firm will bargain with groups demanding inclusive distribution. Bargaining is important because when groups mobilize and exercise power to influence the firm's action, managers often bargain with them to determine which concessions might prevent disruptive political action against the firm. As a result, those groups gain the opportunity to shape what types of goods the firm provides and who receives them. Groups that include a greater proportion of the local population are more likely to have an interest in benefits that are shared widely within the enclave than are those that represent smaller subsets of the local population (Olson 1982:48). When there is mobilization from within a fragmented enclave, the leaders of groups that challenge or support the firm are likely to represent small factions and, as a result, are unlikely to demand inclusive benefits. As the firm bargains with these groups, it gains incentives to engage in targeted distribution. By contrast, in cohesive enclaves, mobilization against the firm is more likely to involve groups that include a broad cross-section of the enclave (as opposed to a narrow faction). Similarly, when the firm seeks support or resources from groups that encompass large swaths of society, those groups are more likely to demand inclusive benefits in exchange for their support. Thus, bargaining creates distinct political incentives to provide inclusive services depending on whether the enclave is fragmented or cohesive.

Second, the degree to which enclaves are fragmented or cohesive influences whether the provision of public goods and social services generates political support for the firm among the masses. Mass opinion is important because it can form the basis of mobilization for or against the firm. Managers have strong incentives to learn about what types of actions win support for their firms - indeed, it is common for firms to commission public opinion polling. Polarization in fragmented enclaves frustrates the use of inclusive distribution to generate support because 
staunch opponents are unlikely to support the firm in exchange for small benefits. Quite simply, if an individual opposes the firm because its activities strongly harm that person's livelihood, investments in public goods will be inadequate to change their view. ${ }^{3}$ In addition, when the firm relies on allies to defend it against opponents within the enclave, these allies are unlikely to take costly actions to support the firm in exchange for the small gain of being afforded access to diffuse benefits; rather, they will require more substantial individual benefits of employment, contracts, or patronage in exchange for their support (see Cammett 2014). By contrast, in cohesive enclaves there are smaller divides between those who support and those who oppose the firm. The lack of polarization creates an audience receptive to inclusive distribution; marginal benefits conferred through social services and public goods can increase support for the firm. More precisely, people in such contexts support or oppose the firm based, in part, on the quality of public services for which they hold the firm accountable. This linking of support for or opposition to the firm with social service quality further incentivizes firms to provide inclusive services as an effective strategy for maintaining support.

This argument that privileges on social structures and organization raises questions about where they come from in the first place and whether they shift over time. I contend that cohesion and fragmentation are inherited, in part, from the particular history of the enclaves before the entry of the firm. Yet, it is clear that these structures do evolve, partially due to social changes beyond any actors' control (such as technical aspects of production), and partially due to the agency of firms and other social actors who seek to reshape the local political arena. In the case studies below, I include discussion of moments in which actors purposefully sought to influence the evolution of interest organization, separating these moments from the proximate causes of distribution. However, it is beyond the scope of this paper to move further up the causal chain

\footnotetext{
${ }^{3}$ See Thachil 2014 for a similar mechanism.
} 
and fully account for the underpinnings of cohesion and fragmentation. In the conclusion, I return to the question of origins and change as an important avenue for future research to uncover the limits and possibilities of private distributive politics.

Naturally, there are limits to the scope conditions of this theory. I anticipate that differences in local social structures and organization will best explain firm behavior in industries similar to mining, where firms make large, fixed investments, experience substantial political risk, and face a set of local actors that can disrupt or protect firms' operations. In addition, my theory is tailored to democratic contexts where contestation is permitted, thereby requiring firms to maintain support from social groups in order to operate. It is specifically meant to explain variation in contexts of contestation; if there are few political pressures on firms, managers have more autonomy and outside forces can influence outcomes. Furthermore, for firms to provide social services or public goods for political gain, there must be a deficit of state provision. Such conditions are found widely in the developing world, but exclude authoritarian regimes that do not allow dissent.

The theory I develop builds on, and contrasts with, the extant literature in four ways. My first claim is that the state is not the only distributer of natural resource rents, as some firms distribute benefits in ways that contribute to social service and public goods provision in their responses to local private politics. This argument departs from the state-centric view that expects distribution to flow only through state coffers. I contend that this conventional view is at odds with the outsized role that firms play in localities in which natural resource industries operate, both in terms of the politics of maintaining order and of economic distribution.

Second, while my approach does not deny that global norms encourage firms to contribute to community development, I contend that these policies offer only a partial 
explanation of firm behavior. When firms are under substantial political pressure, demands to maintain political support overwhelm any commitments to international norms. Actions that might be seen as "responsible" in the eyes of global actors may not lead a firm to gain political support locally. Therefore, voluntary initiatives and global norms will play a minimal role in explaining the ways in which firms engage in private distribution. Only where firms have substantial autonomy due to a lack of political pressures will norms of responsibility be the primary factor shaping behavior.

Third, I claim that firms operating in enclaves that approach the cohesive ideal have greater political incentives for inclusive distribution than do those operating in fragmented enclaves. This argument builds on the literature on extractives that has highlighted unity in communities as a key element in social movement success in blocking projects or gaining more compensation (Sawyer 2004; Bebbington et al 2008, Humphreys Bebbington 2012). In contrast with the dominant approach in this literature, my argument anticipates that fragmented enclaves are not necessarily docile ones; fragmentation of interests in an enclave is distinct from fragility within a particular social movement. Groups that include only a minority of the local population, such as an organization of small scale miners, can be potent political players, especially where conflict entails contentious action like blockading roads. Indeed, groups that represent only a fraction of the population are often internally unified and able to gain additional compensation. Therefore, while the literature has emphasized how fragility internal to groups undermines the power that actors have to make demands, my argument focuses on social and organization fragmentation that affects what groups and individuals seek to gain from firms in exchange for support or acquiescence. 
Finally, my bottom up theory privileges local action over analysis of the multi-level games between local contestation, central states, and global civil society. While I concur that states might augment the need for firms to buy stability by failing to enforce property rights, I contend that whether firms engage in targeted or inclusive distribution is shaped by the actors that exercise de facto power at the local level. In addition, global civil society only rarely becomes sufficiently involved in any particular conflict to influence firm behavior-such cases are the exception rather than the rule. Therefore, my account anticipates that variation will be explained primarily by factors internal to the enclave.

\section{METHODS}

My analysis focuses on four Bolivian mining enclaves that host multinational companies. Mining enclaves in Bolivia are not formally defined; they are substantially smaller than the lowest formal administrative unit of government (the municipality), but somewhat larger than communities, which is the main unit of social organization in the Bolivian Altiplano. As a result, each enclave is composed of multiple communities that are strongly connected to the firm (for more details, see Appendix). To select cases, I compiled a list of large, privately held mines run by multinationals. I eliminated two mines located in areas that were less comparable with the others in terms of their social and political contexts (one in the eastern lowlands, another in an urban area). Out of the remaining seven mines, I selected three owned by separate firms. I selected from the balance of mines (all controlled by one firm) the largest and most comparable. In all cases, communities in the enclaves had high levels of poverty and deficiencies in public services. In all cases, the primary alternative economic activities were agriculture, small-scale mining, and commerce. All parent firms shared the following characteristics: they were based in advanced industrial countries; had internal policies that included commitments to community 
development; released public reports of these activities; and had community relations divisions with professional staff hired specifically to handle negotiations and implement social programs.

My analytical approach uses qualitative and quantitative data for process tracing to determine if the evidence is consistent with hypotheses derived from rival explanations (Fairfield \& Charman 2017). Principally, I draw upon documentary evidence and semi-structured interviews with 152 people, including managers from every major mining firm operating in Bolivia, leaders of community organizations, and union leaders (details on sampling in Appendix). I cite interviews with a code (e.g. LP01). ${ }^{4}$ I also use quantitative data from an original face-to-face household survey of 1,425 people living in the four case study enclaves. ${ }^{5}$ These data allow for observations regarding the populations of each enclave that are not possible with semi-structured interviews, thereby improving process tracing and coding of cases (Seawright 2016).

By analyzing cases within a single country and industry, I hold constant features of national policy, politics, and economic conditions. The set of cases, summarized in Table 1, allows for two pairs of mines that are broadly comparable in terms of technology and size: underground mines Porco and San Carlos (a pseudonym, see appendix), and open-pit mines Kori Kollo and San Cristobal. Holding technology constant is important because the technology of production - whether open-pit or underground - shapes likely environmental costs and the need for firms to purchase land. In addition, the state-owned mining enterprise in Bolivia and smallscale mining cooperatives are able to operate underground mines but not open-pit ones, influencing the benefits these actors can gain by forcibly taking over a mine. Cross-case

\footnotetext{
${ }^{4}$ Table A1 contains a full list.

${ }^{5}$ Details on sampling are provided in the Appendix.
} 
comparisons allow for tests of whether variation can be explained by the actions of the state or firm.

Table 1: Cases $^{6}$

\begin{tabular}{|c|c|c|c|c|}
\hline & Porco & San Carlos & Kori Kollo & San Cristobal \\
\hline $\begin{array}{l}\text { Name of Local } \\
\text { Firm }\end{array}$ & Sinchi Wayra & San Carlos & Inti Raymi & $\begin{array}{c}\text { Minera San } \\
\text { Cristobal }\end{array}$ \\
\hline $\begin{array}{l}\text { Name of } \\
\text { Multinational } \\
\text { Order }\end{array}$ & Glencore & (Anonymous) & $\begin{array}{c}\text { Battle Mountain } \\
\rightarrow \text { Newmont }\end{array}$ & $\begin{array}{c}\text { Apex Silver } \rightarrow \\
\text { Sumitomo }\end{array}$ \\
\hline $\begin{array}{l}\text { Year of } \\
\text { Multinational } \\
\text { Ownership }\end{array}$ & 2005 & 1999 & 1990 & 1997 \\
\hline Technology & Underground & Underground & Open-pit & Open-pit \\
\hline $\begin{array}{l}\text { Size } \\
\text { (workers at peak) }\end{array}$ & 600 & 500 & 1,000 & 1,600 \\
\hline Minerals & Silver / Lead / Zinc & $\begin{array}{l}\text { Silver / Lead / } \\
\text { Zinc }\end{array}$ & Gold & $\begin{array}{c}\text { Silver / Lead / } \\
\text { Zinc }\end{array}$ \\
\hline $\begin{array}{l}\text { Participation in } \\
\text { Global Initiatives }\end{array}$ & GC / ICMM / GRI & GRI & $\begin{array}{c}\text { GC / ICMM / } \\
\text { GRI }\end{array}$ & GC / GRI \\
\hline Origin of Capital & Europe & North America & North America & $\begin{array}{l}\text { North America } \\
\rightarrow \text { East Asia }\end{array}$ \\
\hline $\begin{array}{l}\text { Number of major } \\
\text { communities in } \\
\text { enclave }\end{array}$ & 2 & 4 & 2 & 3 \\
\hline
\end{tabular}

commitments to international norms, as opposed to the structures of the enclaves. My analysis, however, gains most of its power through within-case process tracing (Brady \& Collier 2010). If my argument is correct, there should be a temporal process within each case by which contestation threatens firms' ability to operate, and firms respond by adjusting the way they distribute economic benefits. We should also observe variation in the types of groups making demands on firms in fragmented and coherent enclaves, with the latter being groups that are comprised of more of the local population than the former. Crucially, these groups should

\footnotetext{
${ }^{6}$ For further description of enclaves and firms, see the Appendix.
} 
demand distinct types of benefits, and firms should respond to their demands, rendering distribution either more targeted or more inclusive. Moreover, my theory anticipates differences in the underpinnings of firm support in fragmented or coherent enclaves—only in cohesive enclaves should firms gain (or lose) supporters based upon service quality. Thus, within-case process tracing and quantitative analyses allow for a series of tests of the expectations of my theory.

\section{BOLIVIAN MINING}

The politics of Bolivian mining is typical of extractives industries in many democratic developing countries in that it exhibits widespread contestation and institutional weakness. There are formal institutions that govern mining in Bolivia—most centrally they specify rules that govern access to minerals and how rents from mining should be distributed. These institutions have been weak, however, and social actors bypass them to make demands on firms, bringing private politics into sharp relief. For example, community leaders near one mine stated that when they need funds for development projects they do not seek them from the municipality (that obtains funding from royalties paid by the industry), but instead go directly to the mining firm because "there is a greater chance that the mining company will help us" (M61). There is an implicit threat that if the firm does not provide benefits, there will be social unrest. As a result, managers in the industry complain that property rights are only a "dream" because the "state will never defend your rights" (LP15) in the face of this "blackmail" from groups that make direct demands on the firm (LP23).

While these aspects of Bolivia remain largely unchanged, the period of time includes a shift in the ideology of the national government. In the 1990s and early 2000s, the government 
actively courted foreign capital using market conforming policies to reduce risks for investors. ${ }^{7}$ In 2006, Bolivia took a strong turn to left-leaning nationalist politics with the election of Evo Morales. His administration forced firms into contract renegotiations to capture more rents, and decentralized the distribution of royalty payments to local governments. ${ }^{8}$ The government also threatened nationalization, which was seen as a real threat to firms-for instance, after threatening to nationalize the San Carlos mine, the stock price of the parent firm dropped by the value of its Bolivian assets. Thus, if the state and the policies of the central government drive variation in private distribution, there should be a pattern across all cases of similar changes in the actions by firms as the Morales administration took power.

Yet, despite the rise of nationalism, the state did not dictate how firms should manage local conflicts nor did it serve as an intermediary in most circumstances. None of the major mining firms operating in the country experienced any active oversight regarding their distribution of benefits to locals, but instead managers from all firms suggested that the state put pressure on them to maintain local support and avoid local conflicts (LP2, LP5, LP15, LP22, LP23, LP24, M31). As I will show below, the state rescinded threats to expropriate mines when the firm counted on local support. However, when local opposition and conflict became intense, the state went ahead with expropriation. Most notably, in 2012, the government nationalized the Swiss multinational Glencore's Colquiri mine after the firm lost local support due to violent confrontations between the firm and cooperative (artisanal) miners over control of a mineral deposit. The state also expropriated the Malku Khota project following local conflict. These examples signaled to managers that the threat of nationalization was very real. Ultimately, firms

\footnotetext{
${ }^{7}$ There were conflicts despite the government's support of the industry. For example, in 1996, workers and indigenous groups mobilized against the multinational firm developing the Amayapampa gold mine, effectively blocking the mine's development.

${ }^{8}$ Starting in 2008 producing municipalities gained $15 \%$ of royalties.
} 
understood that, as one manager stated to the international press, beyond the central "government, it is much more important [to work] with local communities and make sure people are happy." ${ }^{9}$ Thus, the state's actions amplified the need for firms to gain and maintain local support, but did not determine how firms distributed benefits.

While all firms faced a similar central state, they were embedded in enclaves with varying local political contexts. The local actor of the Bolivian state, the municipality, largely did not serve as an intermediary between the firm and society_rather the key actors at the local level are community organizations, labor unions, and mining cooperatives that challenge or defend the firms (for survey evidence of individual perceptions of which intermediaries are most important in mining enclaves, see Table 2). Here I introduce these actors in relation to the concepts of fragmentation and cohesion; the case studies provide further detail on their respective roles.

Table 2: Intermediaries Between the Firm and the Population ${ }^{10}$

\begin{tabular}{|l|r|r|}
\hline & $\begin{array}{c}\text { If you needed assistance from } \\
\text { the mine, who would you go to } \\
\text { get it? }\end{array}$ & $\begin{array}{c}\text { If you had a complaint about } \\
\text { the actions of the mine, who } \\
\text { would you present it to? }\end{array}$ \\
\hline Direct to the firm & $20 \%$ & $15 \%$ \\
\hline Community authorities & $63 \%$ & $67 \%$ \\
\hline Union leaders & $13 \%$ & $14 \%$ \\
\hline $\begin{array}{l}\text { [Mining] cooperative } \\
\text { leaders }\end{array}$ & $1 \%$ & $1 \%$ \\
\hline Mayor & $2 \%$ & $3 \%$ \\
\hline
\end{tabular}

First, each community has a traditional organization, or assembly, led by a set of "authorities." These leaders are selected in community assemblies that operate by consensus and

\footnotetext{
${ }^{9}$ Business News Americas, 5/24/2010

${ }^{10} \mathrm{~N}=1,342$. Data from all four cases. A test of differences of proportions shows that the proportion the people who would turn to the mayor is lower than those who would go directly to the firm, through community authorities, or through the union ( $\mathrm{p}<0.01$ in all pairwise comparisons).
} 
include all who are originally from the community. In communities that have multiple factions, assemblies either can be captured by a single group (e.g. landholders), or can include all groups. Enclaves are more cohesive when multiple groups share leadership and when social mobilization is organized through community assemblies. In addition, enclaves consist of multiple communities, each with its own organization, rendering relationships across the assemblies and authorities key to coordinating the bargaining process with the firm. Enclaves are more cohesive where community assemblies coordinate with one another to form unified groups. Second, mine workers employed by private firms are represented by unions. These workers and their families have interests partially aligned with those of the firm — if protests blockade the mine, jobs and wages can be lost—and when workers are from local communities, they can have an interest in public goods and service provision. Some unions ally with community authorities, while others do not, creating differences in the degree of fragmentation in the enclave. Third, not all miners work for firms; many work for small-scale artisanal mining "cooperatives." In Bolivia, as in other developing countries, small-scale artisanal miners conflict with multinational firms over access to mineral deposits. Enclaves with both cooperatives and unions become fragmented because these groups have sharply opposing interests.

In sum, the Bolivian context has a series of characteristics common in the developing world that create intense contestation and give firms incentives to maintain local support. Yet within this context, there has been substantial variation derived from the different combinations of local actors which create distinct pressures on firms as they attempt to maintain their ability to operate. 


\section{SURVEY EXPERIMENT}

Before explaining patterns of distribution by firms, we first must establish that some firms do indeed play a role in service provision and that the state is not the sole actor converting natural resource rents to service provision in the enclaves. This claim is not trivial; the literature on social movements challenging extraction suggests that firms rely purely on clientelism and that it is unlikely that any firms play a substantial role in service provision. Nor is the claim easy to test. Much of the literature is methodologically limited by relying entirely on the accounts of activists who have an interest in minimizing the contributions of firms. We cannot rely on reports from managers either, as they have an interest in overstating their firms' contributions. Instead, we need an independent way to contrast the role of the state and the firm in providing access to services within producing enclaves. To do so, I use survey data as an independent means of analyzing people's experiences with private and state distribution and craft a survey experiment to explicitly compare the two. Following previous work, I measure people's expectations of future benefits to gauge prior experiences (Calvo \& Murillo 2013). Specifically, I crafted questions that probed people's expectations for access to two salient goods-health care and drinking water infrastructure:

"If the [MINING FIRM] [MUNICIPALITY] announced it will undertake a project to improve [community health] [access to drinking water]: Would you expect to have access to it?"

All respondents received questions about health and water (separately); with one half of the respondents randomly presented with the name of the mining firm and the other half with the municipality. I selected these two goods because across all cases they would be appropriate projects to address real needs in the localities that host firms. The "municipality" was chosen as the state provider because it is responsible for health clinics and basic infrastructure. 
The proportion of people who expect to gain access to each good is a first measure of distribution patterns in each enclave (one that will be triangulated in the case studies). To the extent that states, not firms, dominate service provision in mining enclaves, as natural resource politics theories predict, the proportion of people responding "yes" should be lower for the firm treatment than for the state treatment across all enclaves. Moreover, to the degree that there is variation across enclaves, the state-centric literature suggests it will be in terms of differences in state distribution. By contrast, if some firms are direct distributors of rents through inclusive service provision, there should be across-case differences in perceptions of state versus private distribution for some enclaves but not others.

Figure 1: Variation in Expectations for Gaining Access to Promised Benefits

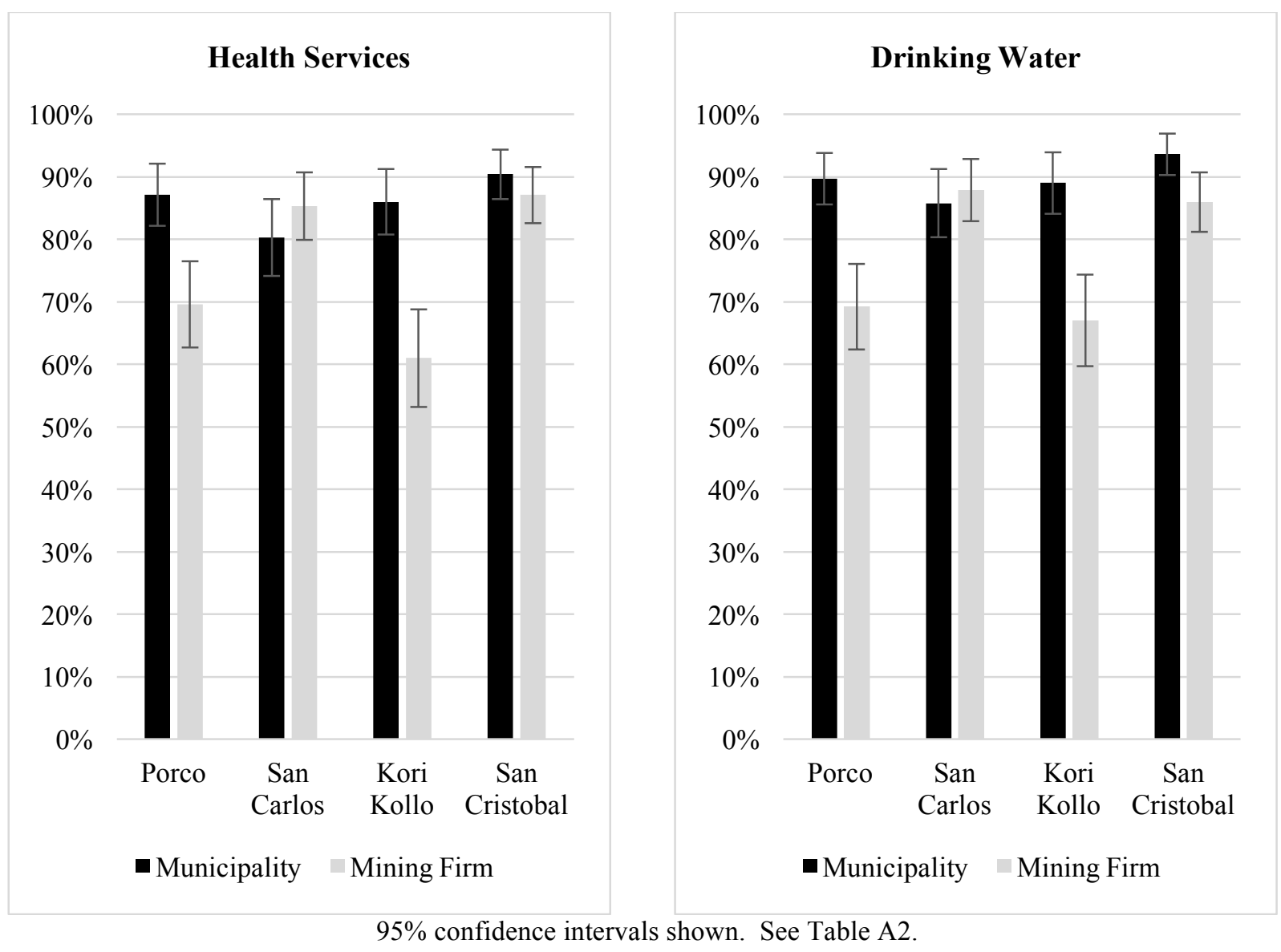


Figure 1 presents the results. The left panel shows the percentage of respondents who expect access to health benefits and the right panel drinking water. Overall, few people expect to be excluded and there are only minor differences in perception of access to services offered by the state across enclaves. There is, however, substantial variation in the effect of the firm treatment on people's expectations. For those in the Porco enclave, the mining firm treatment reduced the probability of people responding yes by 17 percentage points for access to health $(\mathrm{p}<0.01)$ and by 20 points for access to water services $(\mathrm{p}=0.03)$. Similarly, for the Kori Kollo enclave, being told that the mining firm would offer the service reduced the probability that respondents believed they would have access by 25 and 22 percentage points for health and for water services, respectively $(\mathrm{p}<0.01, \mathrm{p}<0.01)$. By contrast, in two of the enclaves, San Carlos and San Cristobal, the difference in the proportion of people who expect to gain access was nonexistent or minor. In San Carlos, there were no statistically significant differences between the two treatments for either good. For San Cristobal, the difference for health access was not statistically significant, but for water there was an eight-point decrease in probability if the mining firm offered the benefit $(\mathrm{p}=.01)$. While there is an effect for access to water in San Cristobal, it is substantially smaller than in the cases of Kori Kollo and Porco (Appendix Table A3).

These results show that people do not perceive the state as the only distributor of public services, supporting the claim that firms are distributing benefits. Furthermore, they show remarkable stability in people's expectations of state provision, suggesting that differences across cases are not due to variation in provision, or lack thereof, by the state. Finally, they reveal puzzling variation in perceptions of firms' contributions. The strength of these data is that they come from representative samples but at the cost of a focus on a few goods at one point in 
time. The results are robust to other measures of firm contributions to community development, including questions about expectations of receiving a range of benefits in the future and experience with distinct organizations in solving community problems (Appendix Table A8 \& A9). The following sections add nuance to the differences in the firms' actions using qualitative data and develop an explanation for this variation.

\section{CASE COMPARISONS}

\section{Underground Mines}

I begin by analyzing two underground mines. They were approximately the same size in terms of employment and production, were both legacy mines with a long history, and were both acquired by multinationals. Yet the two firms' patterns of private distribution varied dramatically.

Porco: Fragmented Enclave

The Porco mine is located in Potosí in a municipality that is also called Porco. A Bolivian firm, COMSUR, ran the Porco mine from its inception in the 1960s until 2005. At that time, the Swiss multinational Glencore bought COMSUR and created a Bolivian subsidiary called Sinchi Wayra. ${ }^{11}$ Glencore is a large senior firm, with hundreds of operations across Latin America, Africa, Asia, and Europe. When the Glencore entered, it encountered an enclave that was home to two rivalrous groups. One consisted of Sinchi Wayra workers, represented by their union, which had $\sim 600$ members in 2014 . The second consisted of mining cooperatives; the largest cooperative, Cooperativa Minera Porco Limitada (CMPL), had 2,500 workers in 2014, and a smaller cooperative, Huanya Porco, had $\sim 350$. Although COMSUR had formal control over the concession, from the 1990s onward, it allowed the two cooperatives to extract from veins no longer viable for the firm; in exchange, the cooperatives sold the minerals to COMSUR.

\footnotetext{
${ }^{11}$ Later, the name was changed once again to Illapa.
} 
The cooperatives did not relinquish access when the Sinchi Wayra took control of the operation. Instead, they expanded and started selling minerals to processing plants outside of the enclave, removing economic gain for Sinchi Wayra from the relationship (C07). Ultimately, the cooperatives and Sinchi Wayra competed over the deposit, resulting in two groups with diametrically opposed interests. With their superior numbers, the cooperatives captured lead positions as community authorities, while workers for the firm were only able to gain some lower positions (C01, C15, C20, C22). The community institutions were, according to leaders, "fractured" and did not aggregate interests (C16). In short, economic structures were highly fragmented, and social organizations could not bridge the divides.

Figure 2: Porco Timeline

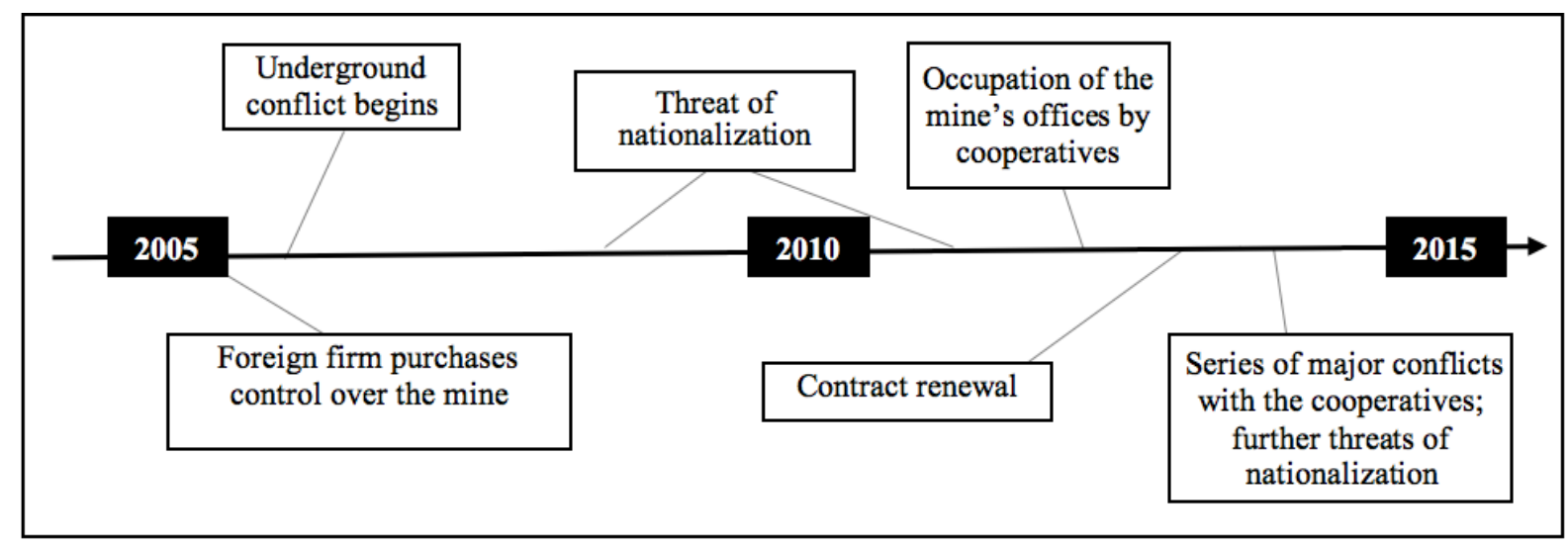

When it took control over the Porco mine, Sinchi Wayra planned to undertake development projects in the enclave in accordance with international norms. An employee involved in community relations recalled: "In 2006, we began with this idea...that it...could become an industrial city...interesting things arose, a jewelry workshop, intensive agricultural cultivation in greenhouses" (C01). Soon thereafter, the firm faced intense pressures from cooperatives that used underground tunnels to invade the mine and steal minerals beyond the 
sections of the deposit allotted to them. These underground incursions continued for years, with little response from the state to enforce property rights (LP15, C01, C02, C15).

Eventually, conflicts grew into large, violent confrontations. One took place in 2013 when cooperative miners clashed over a section of the deposit controlled by Sinchi Wayra, leading the cooperative CMPL to blockade the mine. After this protest, Sinchi Wayra's negotiations with the government to renew its contract created another opportunity for CMPL to challenge the firm's control over the deposit. Community authorities, who were also members of CMPL, attempted to block the contract (C07, C09). Simultaneously, cooperatives and community authorities mobilized to blockade the mine, preventing the transport of minerals and cutting off the water supply. Even after this conflict ended, the situation remained unstable; community and cooperative leaders stated they would "certainly take over the mine" (C09). Concurrently, there was a continual stream of statements from the Morales administration threatening expropriation, amplifying the pressure for keeping local peace and support. There were also some groups that made claims against Sinchi Wayra on the basis of environmental contamination that affected agricultural production, but these groups were weak and unable to place pressure on the firm to the same degree as the cooperatives $(\mathrm{C} 05, \mathrm{CO} 8)$.

How did the firm use economic distribution to respond to these political pressures? Sinchi Wayra sought to maintain the support of its principal ally, the union. Managers did not attempt to reduce divisions in the enclave by building relationships with bridging social groups. For small incursions into the mine's property, managers called on the union to provide muscle for removing cooperative workers instead of turning to the police $(\mathrm{C} 12, \mathrm{C} 07)$. The union also staged counter protests; during the large mobilizations by cooperatives, 400 workers protected the entrance gate to prevent the cooperatives from occupying the mine. As a union leader 
explained, "Sometimes when we are defending our job security, we are also indirectly defending the firm" $(\mathrm{C} 12)$. The union leadership also protested threats from the state, protecting the firm (the government decided not to expropriate citing union resistance).

Support from the union came at a cost to the firm. After the conflict over the contract, workers received a bonus "for their sacrifice" in protesting (C12). Managers sought to maintain worker loyalty by providing safe working conditions and stable employment, something mining cooperatives could not offer (LP15). In addition, managers believed that they retained worker support by providing "a ton of benefits, the most important benefit for them is healthcare" (C01). The union members only accounted for a small portion of the population, thus the distribution of health benefits through the funding of a clinic was not inclusive but targeted (also see Appendix Table A5). Community leaders observed "the union was looking after its own interest" and not that of the enclave when it bargained with the firm for benefits in exchange for protection (C16).

While Sinchi Wayra rewarded its union, it abandoned its intended development programs just as conflicts became intense; local political leaders observed that "with more conflicts, there is less support from the company for the community" (C17). With a constrained budget, managers did not see inclusive distribution as an expedient way of solving political problems (C01). The cooperatives were unlikely to cease their attempts to control the deposit and its valuable minerals in exchange for public spending in the community generally. Moreover, leaders who attempted to bridge multiple groups did not have the power to mobilize (or prevent mobilization) (LP15, C01). For instance, when local leaders made requests to the firm for "projects that will help us...industrialize llama production and... with education" (C18), they were rejected because the firm did not perceive these actors as able to challenge or defend the firm. Ultimately, the firm maintained a small community development program; a senior 
manager compared his mine to others in Bolivia, stating, "I have seen what those guys spend on community development; we don't come close" (LP15). Thus, while political pressure forced Sinchi Wayra to distribute rents to workers, it did not result in investments that contribute to the enclave to diversifying to create the underpinnings of more sustained development beyond extracting non-renewable resources.

This outcome cannot be explained by Sinchi Wayra's rejection of global norms. Although its parent Glencore was not a leader in "responsibility" compared with other senior firms, it was a large firm with over fifty operations throughout the world and over $\$ 200$ billion in revenues (in 2014). During the period of time the firm after it bought the Porco mine, Glencore put in place sustainability policies, reported to GRI and Global Compact, joined ICMM, and promised to spend $1 \%$ of its profit on "community investment." Its local subsidiary had a community relations office staffed by people with backgrounds in running international development projects. However, given the political realities of the enclave, these efforts were bent toward supporting workers not inclusive development projects. Nor can the firm's actions be explained by the state. The belligerence of the Morales administration towards Sinchi Wayra (it nationalized three of the firm's properties) created strong incentives for the firm to prevent conflict and maintain support, and the state failed to provide many basic services at the local level, leaving space for private provision. Yet, the dynamics of contention created local political demands that pushed the firm to engage in targeted distribution that did not augment access to social services and public goods broadly.

San Carlos: Cohesive Enclave

I now turn to the San Carlos mine, which serves as a counterpoint to the previous case. While this deposit also has a long history of mining, current operations began when a small 
foreign firm purchased the nearly dormant mine in the 1990s. The firm was just a few years old and had only one other mine in production at the time it acquired San Carlos. When the mine expanded, it drew people seeking employment from ten small communities in the region, some of whom moved into houses provided by the firm, while others stayed in nearby settlements. Together, this set of communities constituted the enclave and their authorities formed a loose federation to negotiate with the firm and remain, according to one leader, "always together" (A14). The firm not only refrained from undermining this effort to organize interests, but actively supported it by providing advice on how the federation could legally incorporate itself. Importantly, no mining cooperatives operated inside of the enclave, removing the source of fragmentation observed in the previous case. Once the San Carlos mine reopened, the union became a bridge across the distinct social groups and came to represent the entire enclave (A15). In short, unlike the previous case, the enclave was not fractured economically or socially. The firm bargained for support from the union and the community assemblies, key actors whose support was crucial to the firm's ability to operate and, in the process these groups maintained their local power.

Figure 3: San Carlos Timeline

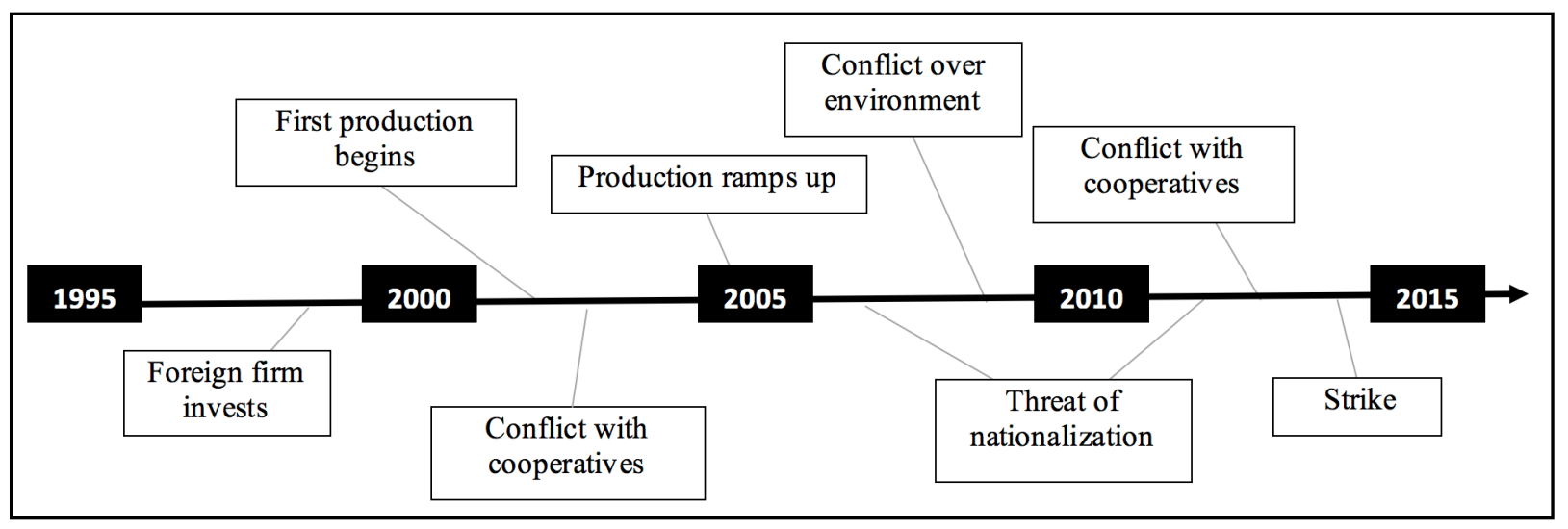


Though cooperatives did not operate inside the enclave, there were cooperatives in the region that employed thousands of workers, had substantial political power, and posed a threat to the firm (A09). In 2002, a group of workers from a cooperative forcibly attempted to take over the mine and oust its multinational owner (A10). There was a strong response from the firm's local allies; as one community leader described, the cooperatives "were more than 1,000 in number...we defended the entrances to the mine using our force" (A15). Unsurprisingly, this was not the last conflict. In 2009, llama herders accused the San Carlos mine of contaminating the area, pointing to malformations in their animals (A03). Later, in 2012, a small group attempted to form a cooperative and take control over a part of the deposit controlled but not actively mined by the San Carlos mining firm. In response, the union and community authorities repelled the invasion (A14, A17). Conflicts with cooperatives never scaled to levels seen in the Porco mine, yet threats continued; as a cooperative leader predicted: "there will be a day in which we recover this mine" and remove the multinational (A10). In addition, as in the previous case, the Morales administration repeatedly threatened to expropriate the San Carlos mine. Again, the union defended the firm and, when the government backed down, officials communicated to the press that it had refrained from expropriation because "the union is against it."

Why did the San Carlos mining firm respond to threats with a distinct distributive approach than Sinchi Wayra did with its Porco mine? In many ways, differences between these two cases are surprising. Both Porco and San Carlos were underground mines facing pressure from cooperatives. When both multinationals entered, managers planned to provide some services in accordance with international norms (A03; C01). Comparisons of the policies adopted by each firm do not reveal major differences in firm signaling of commitments to 
community development (for a detailed comparison, see Appendix Table A16). If anything, theoretical predictions suggest that Sinchi Wayra should have been more likely to contribute to community development, as it was owned by a large established firm, while the San Carlos mine was owned by a younger firm that had a handful of operations and only $\$ 750$ million in revenue (in 2014).

The stance of the national government cannot account for variation, either. The San Carlos mining firm undertook inclusive distribution before Morales was elected and maintained these efforts under his government. When Morales came into power, both firms were subject to a series of nationalization threats at the same time. Variation cannot be explained by the community near the Porco mine being a more docile enclave than San Carlos. Overall, the local political pressures on Sinchi Wayra's Porco mine were substantially greater than those on the San Carlos mine - there were more episodes of major conflict that suspended operations in Porco (four in Porco compared with one in San Carlos), and more participation in protests (26\% of people in Porco's enclave self-reported participating in a protest in the past five years compared with $16 \%$ in San Carlos's enclave.). ${ }^{12}$

To account for the San Carlos mining firm's actions, we must look to the process of contestation between the firm and local groups. Most importantly, there were no internal economic divisions pitting workers against cooperative miners, and the firm did not gain support from one group in the enclave while ignoring the others. Nor did the enclave grow more divided as the mine developed - neither the firm nor social actors sought to reorganize interests in a way that would push the enclave towards fragmentation. Thus, the groups from which the San Carlos mining firm sought to maintain political backing gave the firm incentives to sustain inclusive distribution. The firm negotiated with community authorities who defended the operation and

\footnotetext{
${ }^{12}$ Source: Author's survey. These proportions are statistically significantly different. $N=661, Z=3.29, p=0.001$
} 
"asked for help... for our llamas" (A16). In response, the firm provided services to all agricultural producers in and around the enclave (A03). This investment was responsive to livelihood concerns and supported parts of the local economy that are not dependent on mining. A manager justified this action based on its role in risk reduction, stating "these people are near the project and, at some point, we are going to need them" (A02). The firm also subsidized education for the entire enclave by providing funding for supplies, scholarships, and for 21 teachers to work in the public school (The government budget covered only five teachers.) (A12). According to local leaders "school supplies are for the community of the miners, and for the countryside as well" (A14). The union negotiated to increase these benefits, even though they were available to children whose parents did not work in the mine (LP24). Later, in 2017, the union demanded meetings with managers because they believed that the firm was not contributing enough to local development. Thus, there is direct evidence that the union made demands that would benefit the entire enclave and garnered a response from the firm. ${ }^{13}$

Beyond bargaining, did the San Carlos mining firm gain support in its enclave based, in part, upon service provision? By contrast, was support or opposition to the Sinchi Wayra's Porco mine unrelated to service provision? Answering these questions allows us to find evidence consistent, or inconsistent, with the mechanism that firms in cohesive enclaves have incentives to undertake inclusive distribution to retain mass support. A competing explanation is that Sinchi Wayra was simply unresponsive to popular demands for improving social services around its Porco mine. If this is the case, people who live in Porco's enclave and who observe that social services are of low, or declining, quality should withhold their support for the firm. By contrast, if, as my theory predicts, polarization creates a strong insider-outsider divide, in Porco opinion

\footnotetext{
${ }^{13}$ The firm needed to appease the union which could defend the firm, but the union was also demanding and had mounted strikes to influence management.
} 
should be decoupled from social services and, instead, support for the firm should rest on whether or not people benefit from direct economic ties. Moreover, my argument predicts a distinct relationship for the San Carlos enclave, with people's assessments of social services underlying support for the firm.

In the case study literature, to date scholars have not had the data to answer these questions systematically and instead have relied on interviews with activists and press accounts to infer the bases of support and opposition to firms. By contrast, I use the original survey data with representative samples of each enclave to examine expressed opposition to or support for the firm (on a scale of 1 through 7 , with 1=opposition and 7=support). Figure 4 below shows the distribution of responses to this question in each sample. From this simple analysis, it is possible to interrogate the observable implication of the theory that the more fragmented enclave, Porco, should be more polarized than San Carlos. Indeed, the graphs reveal that in Porco a substantial portion of the population strongly opposes the firm, and a portion of the population strongly supports it. By contrast, in San Carlos the distribution is single-peaked and reveals that there are few outsiders in the enclave. 
Figure 4: Distribution of Support and Opposition to Porco and San Carlos Mines
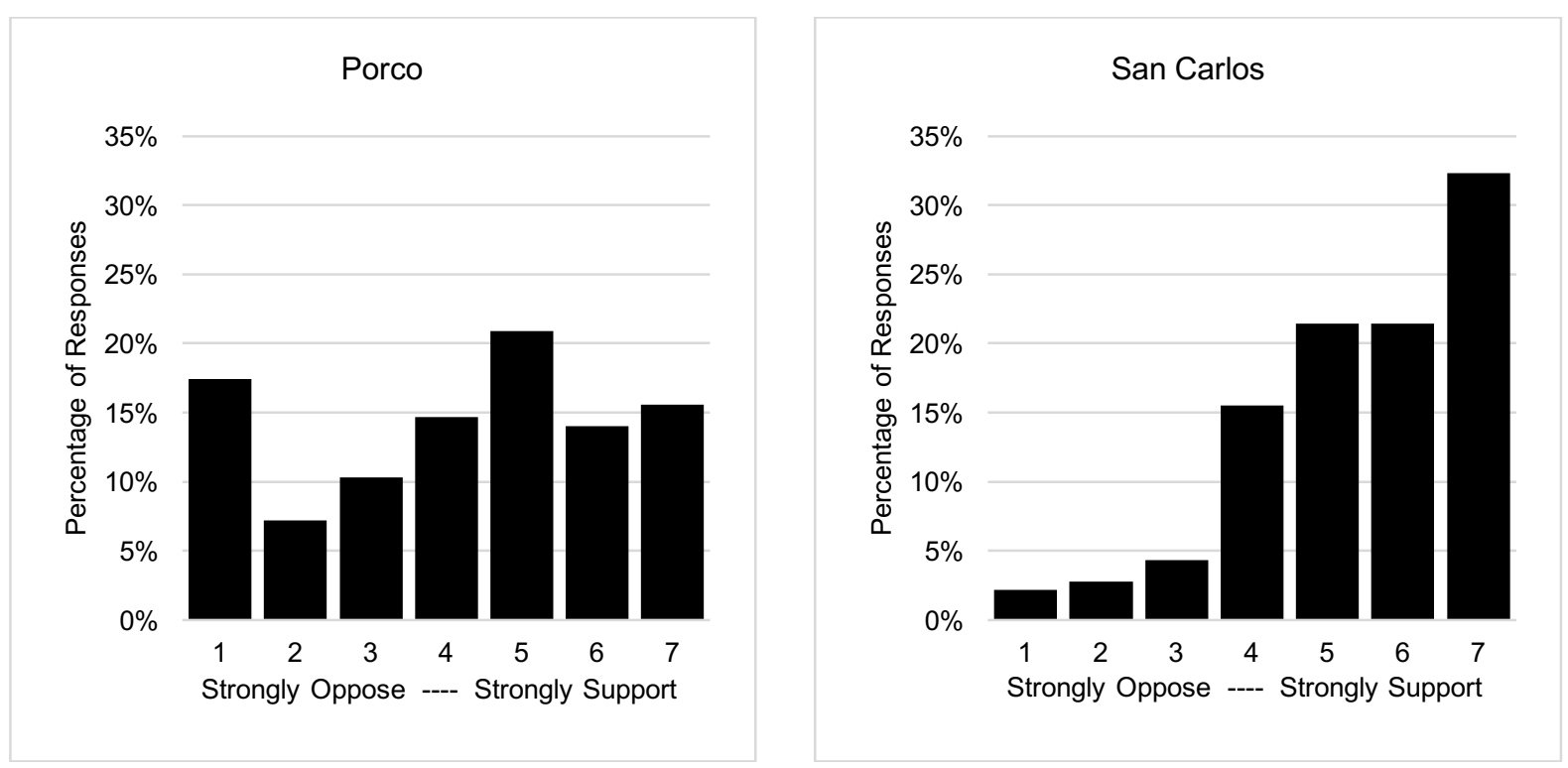

I estimate OLS models in which the dependent variable is support to the firm and the key explanatory variable is the individual's view of Social Services, operationalized as the sum of four questions evaluating the quality of education and health services in the community, with higher values indicating positive responses (standardized to ease interpretation; a description of all variables is in Appendix Table A10). ${ }^{14}$ The relationship between this variable and opinion of the firm does not capture individual clientelistic exchange, but reflects whether support is tied to the overall quality of service provision, a concept related to what Thachil calls "opinion linkages" (2014, p. 167). In light of the priors from the literature that firms maintain support entirely through clientelism, finding such a relationship is unexpected. In addition to the measure of social services, I include a series of controls for variables that can confound the analysis. These include Company Family, which equals 1 if a member of the respondent's family works for the firm, indicating those who have direct economic ties to the firm through employment, as well as controls for Gender, a measure of the individual's Household Assets (e.g.

\footnotetext{
${ }^{14}$ Table A13 reports ordered logit models.
} 
refrigerator, car, etc.), Agriculture production in the household, perceptions of the quality of the natural Environment, and a variable for people who have made Individual Demands on the mining firm. Overall, the measures include both distributional demands, like employment, with livelihood concerns, like perceptions of environmental quality. To be clear, answering this analysis probes specific predictions from theory, rather than serving as an all-encompassing single test (following Seawright 2016; Fairfield and Charman 2017).

Table 3: Association Between Services and Support (Porco and San Carlos) $)^{15}$

(1) (2)

\begin{tabular}{lcc} 
& Porco & San Carlos \\
\hline \multirow{3}{*}{ Social Services } & -0.0291 & $0.286^{* *}$ \\
& $(0.0333)$ & $(0.0693)$ \\
Company Family & $0.769 * *$ & 0.298 \\
& $(0.165)$ & $(0.196)$ \\
Environment & $0.265^{* *}$ & $0.130^{* *}$ \\
& $(0.0760)$ & $(0.0111)$ \\
Agriculture & $-0.296^{* *}$ & -0.0971 \\
& $(0.0342)$ & $(0.166)$ \\
Individual Claims & -0.655 & -0.0779 \\
& $(0.406)$ & $(0.129)$ \\
Gender & $-0.296 *$ & 0.161 \\
& $(0.146)$ & $(0.148)$ \\
Household Assets & $0.622^{* *}$ & 0.438 \\
& $(0.196)$ & $(0.276)$ \\
Constant & $3.450 * *$ & $4.597 * *$ \\
& $(0.497)$ & $(0.226)$ \\
& & \\
Observations & 293 & 289 \\
R-squared & 0.147 & 0.158 \\
\hline
\end{tabular}

OLS regression with bootstrapped standard errors clustered by community. $* * \mathrm{p}<0.01, * \mathrm{p}<0.05$

Table 3 reports the results. Model 2 analyzes the sample from San Carlos and shows that in the case of a cohesive enclave there is an association between social services and support.

\footnotetext{
${ }^{15}$ I use bootstrapped standard errors because the number of clusters is small ( 2 and 4$)$ and the sample sizes for each cluster differ as they are proportionate to the population of each community (Cameron, Gelbach, and Miller 2008). Appendix Table A14 shows similar results with clustered robust standard errors.
} 
While we must interpret the results of cross-sectional regressions with caution, this finding suggests that support for the San Carlos mine is indeed underpinned, in part, by service provision. Thus, the firm's contribution to services is an important component of maintaining local support. By contrast, in Model 1 analyzing the Porco sample, there is no association. ${ }^{16}$ In Porco, people who thought poorly of the condition of services in their community did not necessarily think poorly of the firm. Instead, support or opposition for Sinchi Wayra's Porco mine rests mainly on direct economic relationships between individuals and the firm, especially those who were attached to the firm through employment of a family member, which is congruent with the qualitative evidence that shows that the firm gained most of its support from its own workers. Thus, Sinchi Wayra never developed a political relationship with the enclave that could generate incentives to improve services in order to maintain mass support. Looking beyond social services, the results also show that, following San Carlos mining firm's efforts to support llama herders, agricultural production is not a predictor of opposition to the firm. By contrast, Sinchi Wayra did not undertake such an effort and agricultural outsiders remained in opposition to the firm.

In sum, the Porco and San Carlos enclaves were, respectively, fragmented and cohesive. When conflicts broke out, these social structures resulted in distinct incentives for firms to engage in inclusive distribution. Sinchi Wayra gained support primarily from its workers and did not bargain with actors that demanded inclusive distribution of benefits. By contrast, the San Carlos mining firm bargained with both community assemblies and a union that encapsulated a larger portion of the local population and requested social services. Moreover, in San Carlos's enclave support for the firm became linked to social service quality, creating further incentives for the firm to provide public services in the enclave. While both firms sought to buy stability

\footnotetext{
${ }^{16}$ See appendix for test of differences in the coefficients across models.
} 
using economic resources, only in the San Carlos case was inclusive distribution politically expedient.

\section{Open-Pit Mines}

The technologies and histories of the Kori Kollo and San Cristobal mines differ substantially from the two cases analyzed above. The central societal challenges did not come from cooperatives, as in the previous cases. Instead, the firms operating these mines faced enclaves with distinct structures of social organization. Also, neither firm was threatened with expropriation by the Bolivian state, providing the opportunity to test the explanatory power of my argument where the state is not intensely pressuring the firm.

Kori Kollo: Fragmented Enclave

The Kori Kollo mine was developed by a firm called Inti Raymi that was created with Bolivian capital and then was purchased by the U.S. based firm Battle Mountain. The mine was built between two small agricultural communities in the department of Oruro that were highly socially divided. One community, Chuquiña, consisted of landowners who maintained large herds of sheep, while the other, La Joya, of peasants who subsisted on small scale agriculture. Both communities had internal divisions. Chuquiña had an assembly dominated by the few powerful families that controlled the land to which Inti Raymi needed access for its operation (OM5). In La Joya, a group of families had claims over communally held land, while others were excluded (OM23). In addition, there was never an alliance between these communities that had, as local leaders described, a "historic hatred" for one another (OM13). In short, the enclave was fragmented before the firm entered.

When Inti Raymi sought land to create the Kori Kollo operation, managers first

"negotiated benefits for each family" of landowners to gain access (OM5). The firm also secured 
an agreement with Chuquiña community leaders to resettle Chuquiña a few hundred meters away. Out of these negotiations, the landowners, who were also community authorities, received compensation and became key sources of support for Inti Raymi. Landowners made direct claims on the firm for individual benefits, not communal ones; as one resident noted, "the [community] authorities said that if the land is yours, you fight, but I do not have to fight for you...each one has to negotiate for what he wants" (OM19). Thus, fragmentation influenced the initial bargaining between the firm and local actors.

When operations began at Kori Kollo, Inti Raymi created programs to provide a mixture of inclusive distribution and targeted payouts. For the resettled, Inti Raymi built housing, offered free electricity, invested in healthcare, and provided subsidies for education. For those not displaced, Inti Raymi undertook small infrastructure projects. Most importantly, the firm created a foundation, called the Inti Raymi Foundation (FIR), which implemented "paternalistic" development projects, providing agricultural extension and education services both outside and inside the enclave (OM5). Local factions did not bargain for these benefits; instead these benefits were distributed because managers embraced international standards (OM5, LP21). The firm became a leader in the country and won awards for "responsibility." Thus, by conventional measures, this firm demonstrably followed norms of responsibility.

At the same time, however, to maintain support of key actors within the enclave, management gave out approximately $\$ 230,000$ dollars a year in direct handouts in a clientelistic fashion. According to local leaders, "The company started to divide the people, buying them off, buying off the authorities" (OM12). Those who controlled resources did not bargain for broadly shared benefits; instead they "pocketed the money" from the firm (OM24). Inti Raymi also allocated lucrative contracts, such as transportation of supplies for the operation, to "three or 
four families... who over three years charged the firm a million dollars annually" (OM25). The people who received these contracts "made it so that Inti Raymi did not have any confrontations" (LP21). Thus, the interaction of the firm with the enclave only furthered social fragmentation and those organizations that could have bridged interests failed to do so. For instance, the union did not ally with community authorities and, instead, reproduced the local factions within it by forming subcommittees representing the interests of workers from each of the two communities separately (OM8).

In sum, within the enclave, Inti Raymi engaged in constant bargaining with the few families who provided peace and access to the land the firm needed to operate in exchange for targeted benefits; unlike Porco, insiders were not primarily workers, but families who controlled land. The diverse factions in the community made it susceptible to the firm stoking divisions. Nevertheless, for the first ten years of its operation, the firm also followed global norms to provide inclusive services. The firm maintained these efforts while there were no large protests nor threats of nationalization.

Figure 5: Timeline Kori Kollo

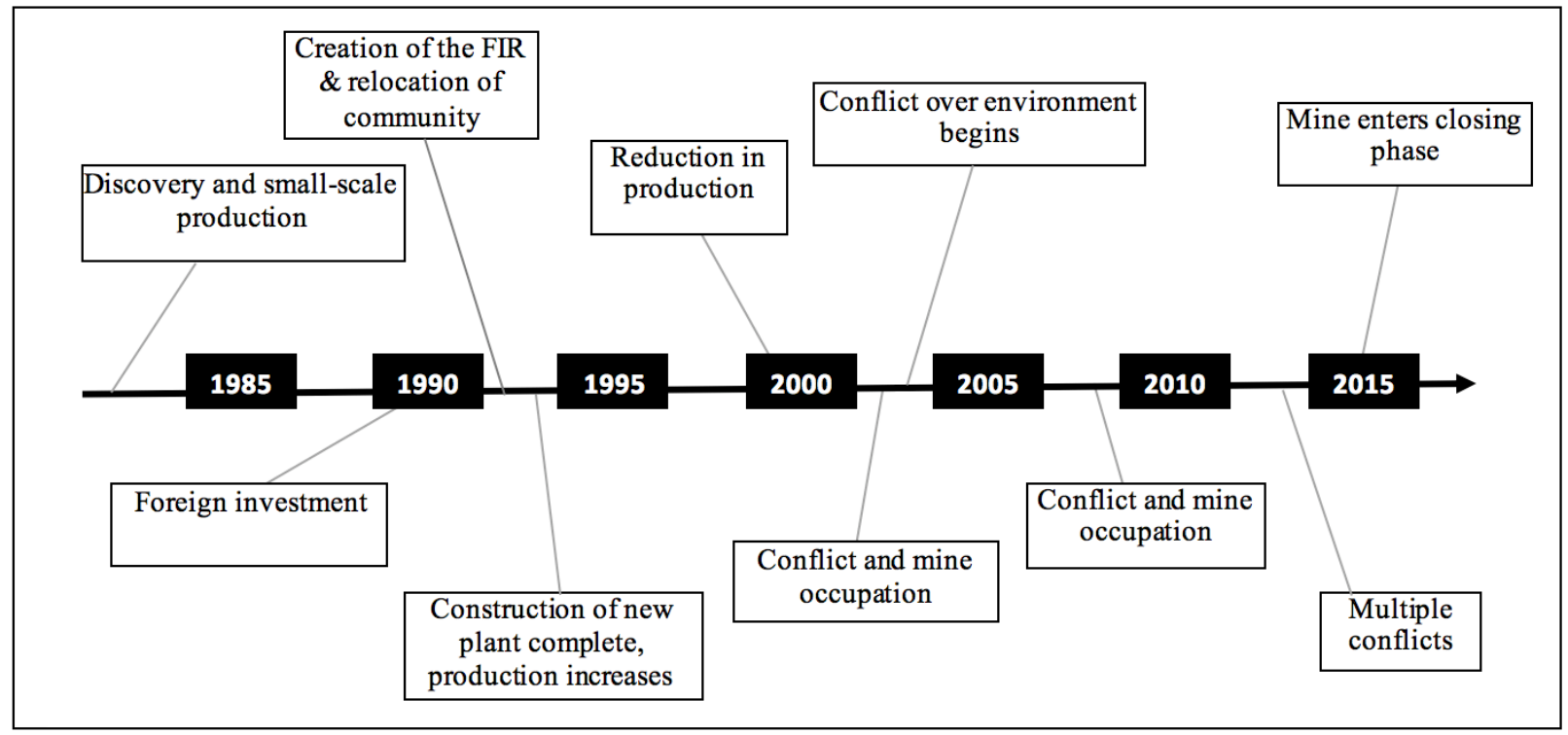


When political pressures increased in the 2000s, Inti Raymi's distributive efforts shifted, rendering inclusive distribution short lived. In 2001, production declined and distribution decreased. The people who, in the past, had made sure the firm had no problems now created conflict, including undertaking a forceful takeover and occupation of the mine, to bargain for a better deal (OM5). To resolve the dispute, managers and protestors reached an agreement, and $\$ 500,000$ in compensation was dedicated, according to the agreement signed by the firm and community leaders, to people "whose land was utilized by the mine." ${ }^{17}$ Breaking with past practices, management concluded that the firm needed to change the role of the FIR, stating: "The FIR was independent from the management of the company. This was an error. I believe that both had to be closely linked because otherwise there is a risk that the objective will be lost, that the money was dispersed... [away from] our political stakeholders." (LP23). Ultimately, in response to political pressure by mobilized factions, Inti Raymi eliminated FIR spending outside of the enclave and integrated FIR into its targeted efforts to maintain its supporters (OM5).

The firm also faced pressure from downstream landowners who asserted that the mine contaminated their lands and water and sought compensation. Numerous environmental groups — some regional and others national—-lodged complaints with the Ministry of Environment and staged protests framed in terms of livelihood concerns. They engaged with international civil society to attempt to put pressure on Inti Raymi's multinational owner. Yet these groups were unable to form alliances with other factions. To defend itself locally, the firm relied on support from its union and community leaders who had received lucrative contracts (LP23). According to members of the environmental group that attempted to protest, the workers "attacked us many times" (OM21). In 2009 and 2013, people from the enclave staged more protests, occupying the mine and demanding, once again, more compensation. Managers

\footnotetext{
${ }^{17}$ Copy of the agreement obtained by the author.
} 
from Inti Raymi negotiated directly with local elites, who led the occupation, and secured a solution "by family," with each gaining "personal benefits" (LP23). Meanwhile, those who made demands for public goods were ineffective because, according to managers, they could not occupy the mine or stop production (LP23).

Ultimately, inclusive distribution scaled down as conflicts scaled up — changes that cannot be attributed to global norms or the state. Indeed, the firm was highlighted at a model actor by the Sustainable Development Business Council of Bolivia in 2004. Moreover, Inti Raymi's parent firm, Battle Mountain, was bought by the mining giant Newmont, a senior firm that had established internal policies mandating "responsible" mining (see Appendix Table A16). Later, in 2008, ownership changed once again, as a local firm took control, but even this firm maintained its public commitment to international norms, such as Global Compact. In addition, the firm changed its pattern of distribution before Morales came into office, and did not change once the political ideology of the central government changed. Ultimately, after years of operation, problems in the enclave related to agriculture, drinking water, and education remained unresolved (OM09, OM10, OM12, OM26). As a local leader recalled: "one part of the community is demanding, asking for the company [to provide benefits], and the other part is defending the company...we wound up with nothing" (OM13).

San Cristobal: Cohesive Enclave

The San Cristobal project began in the 1990s after the discovery of a large zinc deposit under a village also called San Cristobal in Potosí department. The mine was developed by a firm called Minera San Cristobal (MSC) that was initially owned by a small U.S. based multinational called Apex Silver. Like in the case of the Kori Kollo mine, accessing the minerals required large tracts of land and resettling a community. However, unlike the case of Kori 
Kollo, in San Cristobal's enclave, all land was held communally; to access land, MSC needed to gain support from community assemblies composed of all residents in the enclave, rather than a subset of landowners (M01). In these negotiations, community leadership blocked people seeking individual payouts (M05). Also, in contrast to the case of Kori Kollo, where communities had historic fractures, the three communities in San Cristobal's enclave held open meetings in which members of the other communities could participate and called for councils of cross-community authorities when conflicts arose (M62). Integration of the communities continued when the union formed at MSC; community authorities and the union later "merged representation" to form a unified front, according to union leaders (M29). In sum, MSC's enclave was comparatively cohesive, and the underpinnings of this cohesion predated the entry of the firm because, as one manager for MSC stated, the community "structures are something you cannot do anything [about]...they are designed years in advance" (LP8).

During the initial negotiation and bargaining with communities in the enclave over access to land, MSC promised to provide public services, improve infrastructure, and undertake development projects. In addition, MSC funded the creation of a community "foundation" that sought to "create microenterprises for the local population to sustain people who could not work [for the mine]" and share profits and employment throughout the enclave (M46). This action built upon the existing organizational structures and was conducive to the enclave maintaining cohesion. In return, community assemblies granted the firm permission to construct the mine (LP08). Inclusive distribution by MSC cannot be explained by a left-leaning government, as the firm put these programs into place well before the Morales administration came into power (and they continued through his administration). 
Figure 6: Timeline San Cristobal

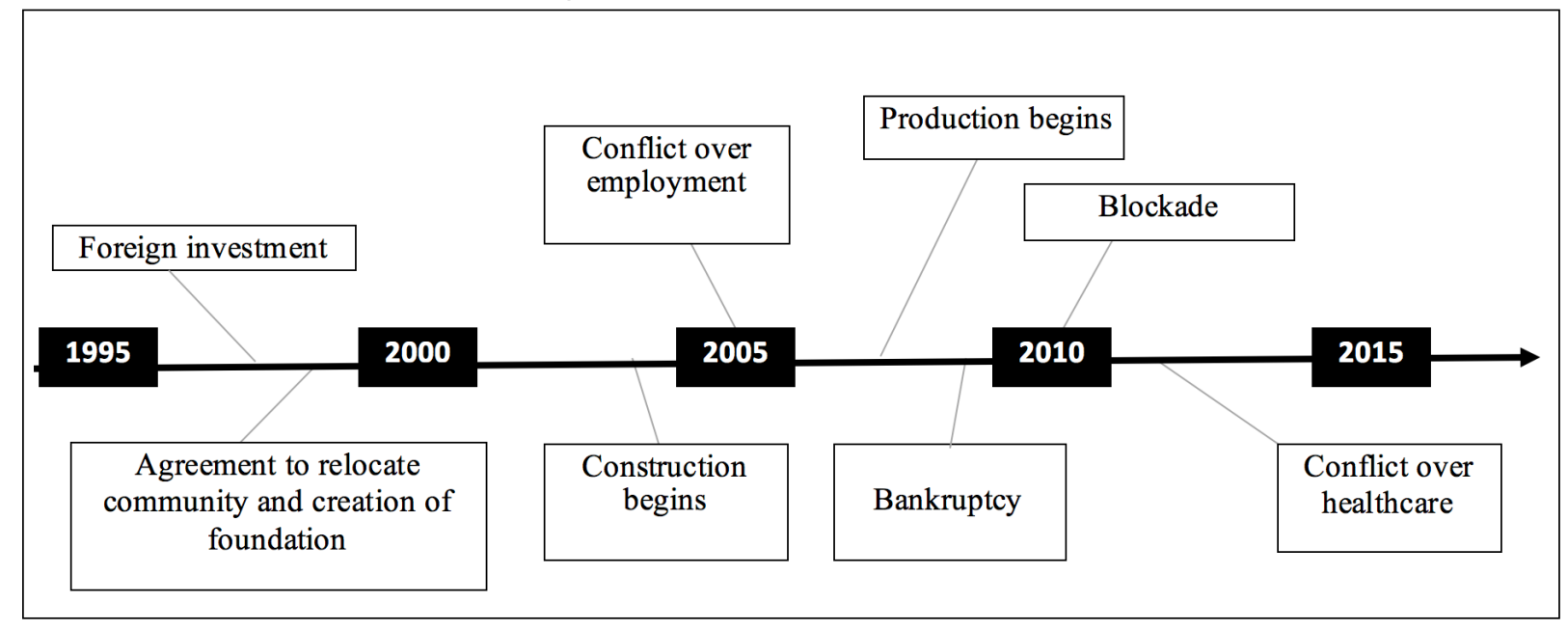

Unsurprisingly, the San Cristobal mine was not free of conflict. In the mid-2000s when construction of the mine began to scale up, tensions over employment opportunities erupted and leaders determined that "MSC was not complying with what we agreed" (M03). In response, the community assemblies organized a strike and a protest. The situation normalized when MSC agreed to more local hiring and job training, but further conflicts occurred. In 2009, a group of peasant organizations made claims that MSC was causing the water table to drop and affecting agriculture. In 2011, protests resulted in an 11-day blockade of production. Reports in the press estimated that this conflict imposed a cost of US $\$ 4$ million. Among protesters' demands were improvements to the provision of healthcare in the community (M3). In contrast to Kori Kollo where a few families led the mobilization, in the San Cristobal enclave, the protests were organized across multiple groups. For example, a community leader recounted that in 2011 "the authorities of the three communities, the union, [and] the workers, we created an alliance together" (M62). A union leader described the labor's role in the protests and strike, referencing his connections to the community, stating: "the union rose up and the communities as well because me, I'm from a nearby community.....my family is there...but the medical services 
weren't what we hoped for' (M29). Thus, key actors sought to maintain bridging ties that underpinned cohesion and the firm did not exploit divisions, such as those between mine workers and others or between those who controlled land and those who did not. Yet, cohesion did not mean greater mobilization, as is sometimes implied in the literature. There were only two instances of major conflict in San Cristobal case, fewer than the repeated conflicts that occurred in Kori Kollo, and a smaller portion of the people who lived in the San Cristobal enclave participated in protests than in Kori Kollo ( $7 \%$ versus $19 \%$ in the five years before the survey). ${ }^{18}$ Instead, cohesion meant that MSC bargained with groups that made demands focused on increasing benefits for the entire enclave, rather than targeted payouts. Thus, these conflicts provided the firm with incentives to undertake inclusive distribution to maintain its ability to operate.

MSC responded to conflicts by redoubling inclusive distribution following each protest. In 2006, the firm created a "consultation council" to bargain with leaders of the enclave's community assemblies. By doing so, MSC reinforced bridging organizations, helping the enclave remain cohesive. The results of these negotiations were a series of development projects in areas such as agriculture. MSC managers maintained the programs even when budget constraints were tight — the owner of MSC, Apex Silver, filed for bankruptcy in 2009—because they believed there would be political costs if they reduced private distribution (LP08). After the 2011 conflict, MSC increased its efforts to provide health services in the enclave. It also undertook a series of projects to benefit outsiders who did not have economic ties with the firm. For example, the firm financed programs to support llama herders and quinoa producers; these efforts mitigated the negative effects that the mine had on the livelihoods of those who remained in agriculture (M34, M14). Outsiders who were not miners gained economic opportunities and

\footnotetext{
${ }^{18} \mathrm{~N}=762, \mathrm{Z}=4.65, \mathrm{p}<0.001$.
} 
the firm made investments in diversifying the economy. These programs came out of direct bargaining with community authorities, selected through assemblies, who represented broad interests. This outcome contrasted strongly with the case of Kori Kollo, where more conflict lead to less inclusive distribution.

Once again, while qualitative evidence is well suited for tracing the processes by which the firm bargained with actors, it cannot tell us about the determinants of support for, or opposition to, each firm. An observable implication of my theory is that support or opposition to the firm operating in a cohesive enclave, San Cristobal, is linked to service provision, thereby creating incentives for the firm to contribute to inclusive service provision. By contrast, support and opposition for the firm operating in the fragmented enclave, Kori Kollo, should be unrelated to service provision. Did MSC gain support through its provision of social services? Was opinion towards Inti Raymi detached from the condition of social services, or could it be that Inti Raymi was penalized by individuals who saw poor service quality and its managers were simply not responsive to these incentives?

Figure 7: Distribution of Support and Opposition to Kori Kollo and San Cristobal
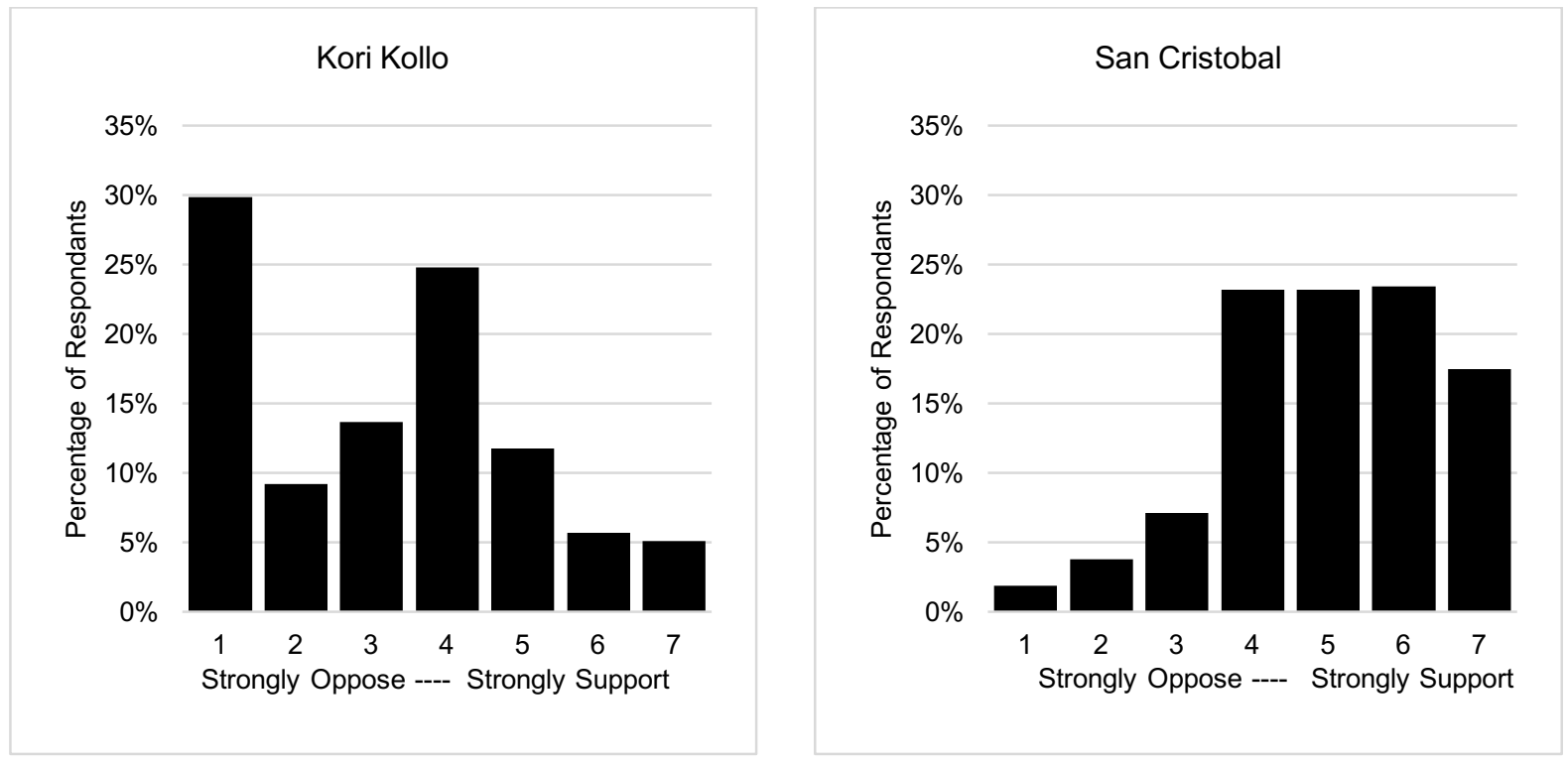
To answer these questions and examine the observable implications of my theory, a turn once again to the survey data. The graphs in Figure 7 show that, as expected, the distribution of support for the firm in Kori Kollo is bimodal, with a large portion strongly opposed and a smaller portion more neutral. By contrast, the cohesive enclave, San Cristobal, is less polarized and does not have a large group of outsiders. To further examine the underpinnings of support and opposition, I fit identical models as in Table 3 with data from the Kori Kollo and San Cristobal enclaves. These models show that in the cohesive enclave, San Cristobal, there is a positive association between support for the firm and perceptions of social services in the enclave. This finding is consistent with the argument that, in cohesive enclaves, support for firms is determined in part by social service provision. By contrast, in Kori Kollo evaluations of social services are unrelated to support or opposition to the firm. ${ }^{19}$ Overall, there is greater opposition to Inti Raymi than MSC, but that opposition in the Kori Kollo enclave is not concentrated among people who believe that social services are poor and declining in their community. Rather, factors that are associated with individual support for the firm, such as whether individuals solicited help directly from the firm, are consistent with a clientelistic exchange. These findings provide additional evidence that firms operating in cohesive enclaves gain or lose support based on services, thus only these firms have incentives for inclusive distribution to maintain mass support.

\footnotetext{
${ }^{19}$ See Appendix for tests of differences in the coefficients across models.
} 
Table 4: Services and Support (Kori Kollo and San Cristobal)

\begin{tabular}{lcc}
\hline & $(3)$ & $(4)$ \\
& Kori Kollo & San Cristobal \\
\hline Social Services & -0.0744 & $0.114^{* *}$ \\
Company Family & $(0.0666)$ & $(0.0258)$ \\
Environment & -0.173 & $0.443^{*}$ \\
& $(0.279)$ & $(0.201)$ \\
Agriculture & $0.353^{*}$ & $0.169 * *$ \\
& $(0.00530)$ & $(0.0108)$ \\
Individual Claims & $-0.508^{* *}$ & -0.192 \\
& $(0.0288)$ & $(0.108)$ \\
Gender & $0.497^{* *}$ & -0.214 \\
& $(0.101)$ & $(0.201)$ \\
Household Assets & $-0.495^{* *}$ & $0.353 * *$ \\
& $(0.0699)$ & $(0.129)$ \\
Constant & $0.213^{* * *}$ & 0.0128 \\
& $(0.0317)$ & $(0.0817)$ \\
& $2.674 * *$ & $3.990 * *$ \\
Observations & $(0.116)$ & $(0.221)$ \\
R-squared & 298 & 377 \\
\hline \multicolumn{2}{c}{ OLS regression with bootstrapped standard errors clustered by community. } \\
\end{tabular}

In sum, although both Inti Raymi and MSC experienced protests and forceful takeovers, the firms responded by providing distinct benefits in response to these challenges. Tracing the processes within each case reveals the way social structures and organization influenced contestation. Despite evolution in social organization in both enclaves, the firms had consistent incentives to engage in distinct types of distribution. The outcomes cannot be explained by differences in the state's provision of goods crowding out private provision, as there were ample opportunities to provide much needed public goods in both enclaves. Nor can they be explained by differences in the state pressuring the firms to provide goods - neither firm was pressured by the state nor did either firm change its patterns of distribution in response to the election of Morales. Variation cannot be explained by major differences between the multinationals 
controlling Inti Raymi and MSC in terms of engagement with international norms either (see Appendix Table A16). ${ }^{20}$ When MSC struck its initial deals with community leaders, the operation was owned by the type of firm that should not have been constrained by global norms - it was a small firm with no other active operations and few assets. Later when the operation was bought by the large Japanese multinational Sumitomo that fit the profile of firms that engage with global norms, local managers still attributed their decisions to local political demands, explaining: "None of this is very social. Instead it is about benefiting the firm. The issue is that if we neglect the communities and they blockade us, instead of losing $\$ 100$, we are going to lose millions" (M01).

\section{CONCLUSION}

The local politics of the Bolivian mining industry provide an opportunity to explore the distinct forms of distribution that arise when firms face social pressure to share the gains of economic activity. All four firms used economic resources to try to buy stability, but the results were far from uniform even within the same industry, country, and category of multinational firms that outwardly commit to contributing to community development. Social pressure resulted in two firms distributing benefits in ways that were both inclusive and sustained, while two did not. I trace these outcomes back to the social structure and organization of the enclaves, which influenced the types of groups with which firms bargained and whether popular support for the firm became linked to social service quality. Ultimately, in cohesive enclaves, firms had political incentives for inclusive distribution, while in fragmented enclaves they did not. This

\footnotetext{
${ }^{20}$ One additional difference between the mines is that Inti Raymi mined gold and MSC did not. While there are not clear theoretical predictions for how this difference could explain outcomes, features that are particular to gold mines, such as the use of cyanide, have been associated with conflicts stemming from environmental concerns. Both mines were accused of environmental degradation by outside groups, but the key difference was the way these accusations played out in the enclaves; only in the case of the Kori Kollo mine was there counter mobilization from a narrow faction that defended the firm.
} 
finding suggests that future research should investigate the underpinnings of these distinct political incentives. Researchers have emphasized cases in which firms augmented fragility in social organizations (Sawyer 2004; Schilling-Vacaflor Forthcoming), but the cases studied in this paper reveal instances in which organizations remained intact and, equally important, insider and outsider divides did not grow to undermine the overall cohesion in the enclave. Further work will need to understand the degree to which interest organization can be shifted by the purposeful action of firms and societal actors, as well as when powerful groups have an interest in maintaining cohesion.

This analysis contributes to the literature on the local politics of natural resources, which has grown as scholars recognize that the impacts (both positive and negative) of these industries are strongest in producing localities. Scholars have debated whether firms contribute to local goods provision, but researchers have not yet empirically examined the private provision of goods to measure or explain variation. Often there is an assumption that the state is all that matters, as firms' actions are symbolic or clientelistic. I show that while firms indeed do engage in targeted distribution, they also provide public goods and services. Furthermore, I offer an explanation for why firms might provide public goods and services in response to political demands, illuminating an often-overlooked aspect of natural resource politics. My analysis focuses on outputs from the firms and it remains beyond the scope of the paper to explain fully development outcomes in the long term. Future research will have to uncover the degree to which actions by firms contribute to development outcomes in resource rich zones as part of analyses of the welfare effects of mining.

More broadly, this paper opens up a new way of analyzing private politics by focusing on its distributive elements. The study of private politics has become increasingly important as 
direct contestation between firms and society has grown and consolidated as a key arena of conflict in a number of industries. Much has been made of the possibility that firms might reduce negative, and augment positive, externalities in response to social pressures, but there has also been skepticism due to the apparent limits in what private politics can achieve. Taking into account the competing pressures that firms face when they seek to gain societal support is necessary for uncovering the conditions under which private politics might push problematic industries to contribute more to local development in the absence of robust state action. 


\section{WORKS CITED}

Arce, M. (2014). Resource extraction and protest in Peru. Pittsburgh, PA: University of Pittsburgh Press.

Arellano-Yanguas, J. (2011a). ¿Minería sin fronteras?: Conflicto y desarrollo en regiones mineras del Peru. Lima, Peru: PUCP.

Arellano-Yanguas, J. (2011b). Aggravating the resource curse: Decentralisation, mining, and conflict in Peru. The Journal of Development Studies, 47(4), 617-638.

Banks, G., Kuir-Ayius, D., Kombako, D., \& Sagir, B. (2013). Conceptualizing mining impacts, livelihoods and corporate community development in Melanesia. Community Development Journal, 48(3), 484-500.

Bebbington, A., Humphreys Bebbington, D., Bury, J., Lingan, J., Muñoz, J. P., \& Scurrah, M. (2008). Mining and social movements: Struggles over livelihood and rural territorial development in the Andes. World Development, 36(12), 2888-2905.

Brady, H. E., \& Collier, D. (2010). Rethinking social inquiry: Diverse tools, shared standards. Lanham, MD: Rowman \& Littlefield Publishers.

Calvo, E., \& Murillo, M. (2013). When parties meet voters: Assessing political linkages through partisan networks and distributive expectations in Argentina and Chile. Comparative Political Studies, 46(7), 851-882.

Cameron, A. C., Gelbach, J.B., \& Miller, D.L. (2008). Bootstrap-based improvements for inference with clustered errors. The Review of Economics and Statistics, 90(3), 414-427.

Cammett, M. (2014). Compassionate communalism: Welfare and sectarianism in Lebanon. Ithaca, NY: Cornell University Press.

Caselli, F., \& Michaels, G. (2013). Do oil windfalls improve living standards? Evidence from Brazil. American Economic Journal: Applied Economics, 5(1), 208-238.

Costanza, J. N. (2016). Mining conflict and the politics of obtaining a social license: Insight from Guatemala. World Development, 79, 97-113.

Dargent, E., Orihuela, J. C., Paredes, M., \& Ulfe, M. E. (2017). Resource booms and institutional pathways: The case of the extractive industry in Peru. Cham, Switzerland: Springer.

Dashwood, H. S. (2012). The rise of global corporate social responsibility: Mining and the spread of global norms. New York, NY: Cambridge University Press.

Dougherty, M. L. (2011). The global gold mining industry, junior firms, and civil society resistance in Guatemala. Bulletin of Latin American Research

Fairfield, T., \& Charman, A. (2017). Explicit Bayesian analysis for process tracing: Guidelines, opportunities, and caveats. Political Analysis, 25(3), 363-380.

Franks, D., Davis, R., Bebbington, A.J., Ali, S.H., Kemp, D., \& Scurrah, M. (2014). Conflict translates environmental and social risk into business costs. PNAS, 111(21), 7576-7581.

Frynas, J.G. (2005). The false developmental promise of corporate social responsibility: Evidence from multinational oil companies. International Affairs, 81(3), 581-598.

Haslam, P.A., \& Tanimoune, N. (2016). The determinants of social conflict in the Latin American mining sector: New evidence with quantitative data. World Development, 78, 401-419.

Henisz, W., Dorobantu, S., \& Nartey, L. (2013). Spinning gold: The financial returns to stakeholder engagement. Strategic Management Journal, 35(1), 1727-1748. 
Hirschman, A. (1958). The strategy of economic development. New Haven, CT: Yale University Press.

Humphreys Bebbington (2012). Consultation, compensation and conflict: Natural gas extraction in Weenhayek Territory, Bolivia. Journal of Latin American Geography, 11(2), 49-71

Jaskoski, M. (2014). Environmental licensing and conflict in Peru's mining sector: A pathdependent analysis. World Development, 64, 873-883.

Jones Luong, P., \& Weinthal, E. (2010). Oil is not a curse: Ownership structure and institutions in Soviet successor states. New York, NY: Cambridge University Press.

Jones Luong, P. (2014). Empowering local communities and enervating the state? Foreign oil companies as public goods providers in Azerbaijan and Kazakhstan. In M. Cammett \& L. MacLean (Eds.), The politics of non-state social welfare (pp. 57-76). Ithaca, NY: Cornell University Press.

Kamlongera, P. J. (2013). The mining boom in Malawi: Implications for community development. Community Development Journal, 48(3), 377-390.

Kitschelt, H., \& Wilkinson, S. I. (2007). Patrons, clients and policies: Patterns of democratic accountability and political competition. New York, NY: Cambridge University Press.

Kotschwar, B., Moran, T., \& Muir, J. (2011). Do Chinese mining companies exploit more? Americas Quarterly, Fall. Retrieved from http://www.americasquarterly.org/do-chinesemining-companies-exploit-more

Markus, S. (2012). Secure property as a bottom-up process: Firms, stakeholders, and predators in weak states. World Politics, 64(2), 242-277.

Olson, M. (1982). The rise and decline of nations. New Haven, CT: Yale University Press.

Özen, H. \& Özen, Ş. (2016). What makes locals protesters? A discursive analysis of two cases in gold-mining industry in Turkey. World Development, 90, 256-268.

Paredes, M. (2016). The glocalization of mining conflict: Cases from Peru. The Extractive Industries and Society, 3(4), 1046-1057

Perla, C. (2012). Extracting from the extractors: The politics of private welfare in the Peruvian mining industry (Unpublished doctoral dissertation). Brown University, Providence, RI.

Ponce, A. F., \& McClintock, C. (2014). The explosive combination of inefficient local bureaucracies and mining production: Evidence from localized societal protests in Peru. Latin American Politics and Society, 56(3), 118-140.

Robinson, J., Torvik, R., \& Verdier, T. (2006). Political foundations of the resource curse. Journal of Development Economics, 79(2), 447-468.

Sawyer, S. (2004). Crude chronicles: Indigenous politics, multinational oil, and neoliberalism in Ecuador. Durham, NC: Duke University Press.

Seawright, J. (2016). Multi-method social science: Combining qualitative and quantitative tools. New York, NY: Cambridge University Press.

Steinberg, J. (2016). Strategic sovereignty: A model of non-state goods provision and resistance in regions of natural resource extraction. Journal of Conflict Resolution, 60(8), 15031528.

Steinberg, J. (2018). Protecting the capital? On African geographies of protest escalation and repression. Political Geography, 62, 12-22.

Thachil, T. (2014). Elite parties, poor voters: How social services win votes in India. New York, NY: Cambridge University Press.

Vogel, D. (2008). Private global business regulation. Annual Review of Political Science, 11, 261-282. 
Weitz-Shapiro, R. (2014). Curbing clientelism in Argentina: Politics, poverty, and social policy. New York, NY: Cambridge University Press.

Zarsky, L., \& Stanley, L. (2013). Can extractive industries promote sustainable development? A net benefits framework and a case study of the Marlin mine in Guatemala. The Journal of Environment \& Development, 22(2), 131-154. 
APPENDIX

1. Description of Fieldwork

2. Description of Survey

3. Definition and Characteristics of the Enclaves

4. Survey Experiment

5. Alternative Measures of Firm Contributions

6. Support and Opposition to the Firm

7. Comparison of Firm Policies 


\section{DESCRIPTION OF FIELDWORK}

Data collection for this paper proceeded in the following steps. First, I negotiated access to each firm. With permission from high level managers in each firm, I was granted access to key "community relations" staff. Specifically, I interviewed senior managers who define strategy, as well as lower level staff who implement social service projects and bargain with community members on a day-to-day basis. For each case study firm, I interviewed managers in a variety of other related positions within the firm to gain more information about how they handled community relations (e.g. environmental, human resources). In the process, I travelled to each mine site, viewed the installation, and the enclaves. For Kori Kollo and San Cristobal, I was also able to interview people who had formerly worked in each mining firm to gain the perspective of those who were outside of the firm but who understood the history of events. I also interviewed managers from other mines not included in the case studies to build an understanding of the context. These interviews covered all large mining firms operating in the country, as well as a selection of smaller firms.

In each enclave, I interviewed current and former community authorities, union leaders, and, where present, cooperative leaders. While I could gain access to these groups, some interviewees were clearly suspicions of a foreign researcher, especially since some had observed me speaking with the firm's management. It is unclear whether those suspicions amplified or diminished people's criticisms of the firm - some believed that a foreigner might legitimize their claims against the firm, while others suspected I might report the contents of the interviews to management (despite my assurances of anonymity when I gained consent). For the case of San Cristobal, a graduate student travelled to the enclave to conduct additional interviews (24) and follow up on those I had conducted.

I undertook the bulk of the interviews before the survey took place in 2015. By that time, I had already coded the outcomes of the cases, although I did not know whether the survey results would comport with my analysis of interview and documentary evidence. After the survey, I returned to Kori Kollo, Porco, and San Cristobal, and presented the results to community leaders (I was not able to access San Carlos). These meetings created additional opportunities to interview community leaders and to triangulate survey findings and past fieldwork. During these trips, I did not speak with the management of mining firms in the enclaves to avoid the perception of being related with management.

Overall, the interviews averaged 50 minutes. In total, 93 people were recorded. For the remaining interviews, we did not use a recorder, either because the person did not agree to recording, or (more often) because it appeared that recording would make the person uncomfortable. One particularly difficult issue in this fieldwork was anonymity. All interviews are cited anonymously and information that can clearly identify individuals is not directly quoted. However, managers for the parent firm of the San Carlos mine did not give me permission to use the name of their firm in publications. While I committed to withholding the name of the firm, I did not offer to change details to mask the case, as it would be nearly impossible given the small number of firms operating in the country. This balance, I hope, allows for a thorough analysis of case material while creating a minimal barrier to exposing the firms that I study. 


\section{Table A1: Interviews}

\begin{tabular}{|c|c|}
\hline A01, NGO, Phone, 10/2014, 51 minutes & $\begin{array}{l}\text { M12, Manager Mining Firm, Potosí, 11/2013, } 65 \\
\text { minutes }\end{array}$ \\
\hline $\begin{array}{l}\text { A02, Manager Mining Firm, Potosí, 11/2014, } 53 \\
\text { minutes }\end{array}$ & $\begin{array}{l}\text { M13, Manager Mining Firm, Potosí, 11/2013, } 14 \\
\text { minutes }\end{array}$ \\
\hline $\begin{array}{l}\text { A03, Manager Mining Firm, Potosí, 11/2014, } 47 \\
\text { minutes }\end{array}$ & M14, Community Leader, Potosí, 11/2013, 33 minutes \\
\hline $\begin{array}{l}\text { A04, Manager Mining Firm, Potosí, 11/2014, } 26 \\
\text { minutes }\end{array}$ & M15, Community Leader, Potosí, 11/2013, 32 minutes \\
\hline A05, Community Leader, Potosí, 11/2014, 50 minutes & $\begin{array}{l}\text { M16, Community Leader, Potosí, 11/16/2013, 8/19/14, } \\
\text { 47, } 57 \text { minutes }\end{array}$ \\
\hline A06, Community Leader, Potosí, 11/2014, 48 minutes & M17, Local Government, Potosí, 11/2013, 26 minutes \\
\hline A07, Government Official, Potosí, 11/2014, 20 minutes & $\begin{array}{l}\text { M18, Manager Mining Firm, Potosí, 11/2013, } 68 \\
\text { minutes }\end{array}$ \\
\hline A08, Government Official, Potosí, 11/2014, 10 minutes & M19, Community Leader, Potosí, 11/2013, 52 minutes \\
\hline A09, Government Official, Potosí, 11/2014, 43 minutes & $\begin{array}{l}\text { M20, Community Leader, Potosí, 11/17/2013, 8/12/14, } \\
40 \text { minutes }\end{array}$ \\
\hline A10, Mining Cooperative, Potosí, 11/2014, 40 minutes & $\begin{array}{l}\text { M21, Community Leader, Potosí, 11/17/2013, 8/11/14, } \\
89 \text { minutes }\end{array}$ \\
\hline $\begin{array}{l}\text { A11, Manager Mining Firm, Potosí, 11/2014, } 15 \\
\text { minutes }\end{array}$ & M22, Community Leader, Potosí, 11/2013, 44 minutes \\
\hline A12, School Director, Potosí, 11/2014, 25 minutes & M23, Community Leader, Potosí, 11/2013, 27 minutes \\
\hline A13, Community Leader, Potosí, 11/2014, 40 minutes & M24, Community Leader, Potosí, 11/2013, 12 minutes \\
\hline A14, Community Leader, Potosí, 11/2014, 43 minutes & M25, Community Leader, Potosí, 11/2013, 20 minutes \\
\hline A15, Community Leader, Potosí, 11/2014, 43 minutes & M26, Mining Cooperative, Potosí, 11/2013, 20 minutes \\
\hline A16, Community Leader, Potosí, 11/2014, 60 minutes & M27, Mining Cooperative, Potosí, 11/2013, 15 minutes \\
\hline A17, Union, Potosí, 11/2014, 45 minutes & M28, Community Leader, Potosí, 11/2013, 15 minutes \\
\hline A18, Community Leader, Potosí, 11/2014, 20 minutes & M29, Union, Potosí, 11/2013, 36 minutes \\
\hline A19, Community Leader, Potosí, 11/2014, 20 minutes & M30, Community Leader, Potosí, 11/2013, 54 minutes \\
\hline $\begin{array}{l}\text { A20, Manager Mining Firm, Potosí, 11/2014, } 18 \\
\text { minutes }\end{array}$ & $\begin{array}{l}\text { M31, Manager Mining Firm, La Paz, 2/24/2014, } \\
8 / 18 / 14,10 / 10 / 2016,95 \text { minutes }\end{array}$ \\
\hline $\begin{array}{l}\text { A21, Manager Mining Firm, Potosí, 11/2014, } 20 \\
\text { minutes }\end{array}$ & $\begin{array}{l}\text { M32, Manager Mining Firm, Potosí, 8/2014, } 64 \\
\text { minutes }\end{array}$ \\
\hline $\begin{array}{l}\text { C01, Manager Mining Firm, Potosí, 11/2014, } 97 \\
\text { minutes }\end{array}$ & $\begin{array}{l}\text { M33, Manager Mining Firm, Potosí, 8/2014, } 36 \\
\text { minutes }\end{array}$ \\
\hline $\begin{array}{l}\text { C02, Manager Mining Firm, Potosí, 11/2014, } 40 \\
\text { minutes }\end{array}$ & M34, Community Leader, Potosí, 8/2014, 11 minutes \\
\hline C03, Community Leader, Potosí, 11/2014, 30 minutes & M36, Community Leader, Potosí, $8 / 2014,48$ minutes \\
\hline C04, Government Official, Potosí, 11/2014, 30 minutes & M37, Community Leader, Potosí, 8/2014, 35 minutes \\
\hline C05, Environmental NGO, Potosí, 11/2014, 20 minutes & M38, Community Leader, Potosí, 8/2014, 11 minutes \\
\hline C06, Environmental NGO, Potosí, 11/2014, 16 minutes & M41, Community Leader, Potosí, 8/2014, 20 minutes \\
\hline C07, Mining Cooperative, Potosí, 11/2014, 66 minutes & M42, Community Leader, Potosí, 8/2014, 20 minutes \\
\hline C08, Environmental NGO, Potosí, 11/2014, 40 minutes & M43, Community Leader, Potosí, 8/2014, 41 minutes \\
\hline C09, Mining Cooperative, Potosí, 11/2014, 60 minutes & M45, Community Leader, Potosí, 8/2014, 26 minutes \\
\hline C10, Government Official, Potosí, 11/2014, 30 minutes & M46, Community Leader, Potosí, 8/2014, 51 minutes \\
\hline C11, Community Leader, Potosí, 11/2014, 20 minutes & M47, Community Leader, Potosí, 8/2014, 34 minutes \\
\hline C12, Union, Potosí, $11 / 2014,90$ minutes & M48, Community Leader, Potosí, 8/2014, 60 minutes \\
\hline C14, Community Leader, Potosí, 11/2014, 20 minutes & M49, Community Leader, Potosí, 8/2014, 23 minutes \\
\hline C15, Environmental NGO, Potosí, 11/2014, 35 minutes & M51, Community Leader, Potosí, 8/2014, 30 minutes \\
\hline C16, Community Leader, Potosí, 10/2016, 60 minutes & M52, Community Leader, Potosí, 8/2014, 14 minutes \\
\hline C17, Local Government, Potosí, 10/2016, 60 minutes & M53, Community Leader, Potosí, 8/2014, 22 minutes \\
\hline C18, Local Government, Potosí, 10/2016, 60 minutes & M56, Community Leader, Potosí, 8/2014, 23 minutes \\
\hline C18, Local Government, Potosí, 10/2016, 60 minutes & M58, Community Leader, Potosí, 8/2014, 24 minutes \\
\hline
\end{tabular}




\begin{tabular}{|c|c|}
\hline C20, Community Leader, Potosí, 10/2016, 60 minutes & $\begin{array}{l}\text { M59, Environmental NGO, Phone, 12/2014, } 60 \\
\text { minutes }\end{array}$ \\
\hline C21, Community Leader, Potosí, 10/2016, 60 minutes & $\begin{array}{l}\text { M6, Manager Mining Firm, Potosí, 11/2013, } 60 \\
\text { minutes }\end{array}$ \\
\hline C22, Community Leader, Potosí, 10/2016, 60 minutes & M60, Community Leader, Potosí, 10/2016, 60 minutes \\
\hline $\begin{array}{l}\text { LP01, Manager Mining Firm, La Paz, 7/2014, } 90 \\
\text { minutes }\end{array}$ & M61, Community Leader, Potosí, 10/2016, 36 minutes \\
\hline $\begin{array}{l}\text { LP02, Manager Mining Firm, La Paz, 7/2014, } 44 \\
\text { minutes }\end{array}$ & M62, Community Leader, Potosí, 10/2016, 54 minutes \\
\hline $\begin{array}{l}\text { LP03, Centro de Estudios para el Desarollo Laboral y } \\
\text { Agrario, La Paz, 7/2014, } 102 \text { minutes }\end{array}$ & OM1, Environmental NGO, Oruro, 8/2014, 55 minutes \\
\hline $\begin{array}{l}\text { LP04, Manager Mining Firm, La Paz, 7/2014, } 65 \\
\text { minutes }\end{array}$ & $\begin{array}{l}\text { OM10, Community Leader, Oruro, 11/2014, } 120 \\
\text { minutes }\end{array}$ \\
\hline $\begin{array}{l}\text { LP05, Conf. Empresarios Privados de Bolivia, La Paz, } \\
\text { 7/2014, } 64 \text { minutes }\end{array}$ & $\begin{array}{l}\text { OM11, Community Leader, Oruro, 11/2014, } 120 \\
\text { minutes }\end{array}$ \\
\hline LP06, Fundacion Tierra, La Paz, 7/2014, 45 minutes & $\begin{array}{l}\text { OM12, Community Leader, Oruro, 11/6/2014, } \\
11 / 10 / 2014,120 \text { minutes }\end{array}$ \\
\hline $\begin{array}{l}\text { LP07, Fondo de Financiamiento para la Mineria, La } \\
\text { Paz, 7/2014, } 25 \text { minutes }\end{array}$ & $\begin{array}{l}\text { OM13, Community Leader, Oruro, 11/2014, } 100 \\
\text { minutes }\end{array}$ \\
\hline $\begin{array}{l}\text { LP08, Manager Mining Firm, La Paz, 7/2014, } 60 \\
\text { minutes }\end{array}$ & $\begin{array}{l}\text { OM14, Community Leader, Oruro, 11/2014, } 100 \\
\text { minutes }\end{array}$ \\
\hline $\begin{array}{l}\text { LP09, Former Vice Minister of Mining and } \\
\text { Researcher, La Paz, 7/2014, } 60 \text { minutes }\end{array}$ & $\begin{array}{l}\text { OM15, Community Leader, Oruro, 11/2014, } 100 \\
\text { minutes }\end{array}$ \\
\hline $\begin{array}{l}\text { LP10, Manager Mining Firm, La Paz, 7/2014, } 60 \\
\text { minutes }\end{array}$ & $\begin{array}{l}\text { OM16, Community Leader, Oruro, 11/2014, } 100 \\
\text { minutes }\end{array}$ \\
\hline LP11, CONOMAQ, La Paz, 7/2014, 60 minutes & $\begin{array}{l}\text { OM17, Community Leader, Oruro, } 11 / 2014,100 \\
\text { minutes }\end{array}$ \\
\hline $\begin{array}{l}\text { LP12, Environment Ministry, La Paz, 7/2014, } 50 \\
\text { minutes }\end{array}$ & $\begin{array}{l}\text { OM18, Community Leader, Oruro, 11/2014, } 15 \\
\text { minutes }\end{array}$ \\
\hline $\begin{array}{l}\text { LP13, Manager Mining Firm, La Paz, 7/2014, } 60 \\
\text { minutes }\end{array}$ & $\begin{array}{l}\text { OM19, Community Leader, Oruro, } 11 / 2014,70 \\
\text { minutes }\end{array}$ \\
\hline $\begin{array}{l}\text { LP14, Liga Defensa de Medio Ambiente, La Paz, } \\
\text { 7/2014, } 24 \text { minutes }\end{array}$ & OM2, Community Leader, Oruro, 8/2014, 20 minutes \\
\hline $\begin{array}{l}\text { LP15, Manager Mining Firm, La Paz, 7/2014, } 70 \\
\text { minutes }\end{array}$ & $\begin{array}{l}\text { OM20, Community Leader, Oruro, } 11 / 2014,70 \\
\text { minutes }\end{array}$ \\
\hline $\begin{array}{l}\text { LP16, Conservación Internacional, La Paz, 7/2014, } 16 \\
\text { minutes }\end{array}$ & $\begin{array}{l}\text { OM21, Environmental NGO, Oruro, 11/2014, } 72 \\
\text { minutes }\end{array}$ \\
\hline $\begin{array}{l}\text { LP17, Manager Mining Firm, La Paz, 7/2014, } 70 \\
\text { minutes }\end{array}$ & $\begin{array}{l}\text { OM22, Community Leader, Oruro, 10/2016, } 100 \\
\text { minutes }\end{array}$ \\
\hline $\begin{array}{l}\text { LP18, Ministerio de Minera y Metalurgia, La Paz, } \\
8 / 2014,70 \text { minutes }\end{array}$ & $\begin{array}{l}\text { OM23, Community Leader, Oruro, 10/2016, } 100 \\
\text { minutes }\end{array}$ \\
\hline $\begin{array}{l}\text { LP19, Manager Mining Firm, La Paz, 8/2014, } 35 \\
\text { minutes }\end{array}$ & $\begin{array}{l}\text { OM24, Community Leader, Oruro, } 10 / 2016,40 \\
\text { minutes }\end{array}$ \\
\hline $\begin{array}{l}\text { LP20, Manager Mining Firm, La Paz, 8/2014, } 54 \\
\text { minutes }\end{array}$ & $\begin{array}{l}\text { OM25, Community Leader, Oruro, 10/2016, } 20 \\
\text { minutes }\end{array}$ \\
\hline LP21, Community Leader, La Paz, 8/2014, 60 minutes & $\begin{array}{l}\text { OM26, Community Leader, Oruro, } 10 / 2016,45 \\
\text { minutes }\end{array}$ \\
\hline $\begin{array}{l}\text { LP22, Manager Mining Firm, La Paz, 11/2014, } 72 \\
\text { minutes }\end{array}$ & OM3, Community Leader, Oruro, 8/2014, 20 minutes \\
\hline $\begin{array}{l}\text { LP23, Manager Mining Firm, La Paz, 11/2014, } 67 \\
\text { minutes }\end{array}$ & OM4, Community Leader, Oruro, 8/2014, 20 minutes \\
\hline $\begin{array}{l}\text { LP24, Manager Mining Firm, La Paz, 11/2014, } 60 \\
\text { minutes }\end{array}$ & $\begin{array}{l}\text { OM5, Manager Mining Firm, Oruro, } 8 / 2014,78 \\
\text { minutes }\end{array}$ \\
\hline $\begin{array}{l}\text { M01, Manager Mining Firm, Potosí, 11/12/2013, } \\
8 / 18 / 14,185 \text { minutes }\end{array}$ & $\begin{array}{l}\text { OM6, Manager Mining Firm, Oruro, 8/2014, } 78 \\
\text { minutes }\end{array}$ \\
\hline
\end{tabular}




\begin{tabular}{|l|l|}
\hline $\begin{array}{l}\text { M02, Manager Mining Firm, Potosí, 11/2013, 185 } \\
\text { minutes }\end{array}$ & OM7, Researcher, Oruro, 11/2014, 45 minutes \\
\hline M03, Community Leader, Potosí, 11/2013, 73 minutes & OM8, Union, Oruro, 11/2014, 40 minutes \\
\hline $\begin{array}{l}\text { M04, Community Leader, Potosí, 11/13/2013 / } \\
8 / 11 / 14,73,40 \text { minutes }\end{array}$ & $\begin{array}{l}\text { OM9, Community Leader, Oruro, 11/2014, 120 } \\
\text { minutes }\end{array}$ \\
\hline $\begin{array}{l}\text { M05, Community Leader, Potosí, 11/2013, 135 } \\
\text { minutes }\end{array}$ & U01, Local Government, Potosí, 8/2014, 54 minutes \\
\hline $\begin{array}{l}\text { M07, Manager Mining Firm, Potosí, 11/2013, 82 } \\
\text { minutes }\end{array}$ & U02, Local Government, Potosí, 8/2014, 30 minutes \\
\hline $\begin{array}{l}\text { M08, Manager Mining Firm, Potosí, 11/2013, 60 } \\
\text { minutes }\end{array}$ & U03, Community Leader, Potosí, 8/2014, 30 minutes \\
\hline $\begin{array}{l}\text { M09, Manager Mining Firm, Potosí, 11/2013, 24 } \\
\text { minutes }\end{array}$ & U04, Community Leader, Potosí, 8/2014, 12 minutes \\
\hline $\begin{array}{l}\text { M10, Manager Mining Firm, Potosí, 11/2013, 94 } \\
\text { minutes }\end{array}$ & U05, Local Government, Potosí, 8/2014, 24 minutes \\
\hline $\begin{array}{l}\text { M11, Manager Mining Firm, Potosí, 11/2013, } 94 \\
\text { minutes }\end{array}$ & \\
\hline
\end{tabular}

\section{DOCUMENTARY EVIDENCE}

I gathered a variety of types of documentary evidence. I searched local newspapers, $E l$ Diario, La Razón, El Potosí, and La Patria, for a series of keywords, generating a press chronology of 1,500 articles published between 2003 and 2015. The search terms were the name of each firm, each mine, and each community in which the mine was located. I also conducted searches on all mining industry related articles about Bolivia in Business News Americas for the period between 2003 and 2015. When these articles referred to specific firms in the case studies, I did not cite the source of the article because that would create a direct link to the firm. In addition, I gathered each firm's public reporting related to production, profits, and community investments ('Sustainability Reports').

\section{DESCRIPTION OF SURVEY}

I commissioned the organization Ciudadania in Cochabamba to implement the survey, completed in July and August of 2015. All communities near to and strongly affected by mines were included (see below for details). Within each community, the survey team randomly selected a sample of population proportionate to the size of the community (starting from central points selected using satellite images and surveying each Nth household). To ensure that enumerators followed the sampling plans, Ciudadania collected GPS coordinates for each interview. To increase response rates, the survey team discussed the objectives of the study with community leaders and respondents received a package of school supplies. Overall, the rejection rate was low (5\%), but in $48 \%$ of households no one answered the door after multiple attempts (including evenings and weekends); this high percentage was expected, given the rural context in which many people either work in the fields, in the mines, or migrate to urban centers while maintaining a household in the countryside. 


\section{DEFINITION AND CHARACTERISTICS OF THE ENCLAVES}

A key unit of analysis is the enclave, which I define as the geographic area where production takes place that is highly influenced by a firm in terms of economic ties and exposure to negative externalities. As this unit is not determined by preexisting administrative structures, I needed to define the enclave through the course of the research. For all mines, the set of communities in the area directly affected by the firm's operations was clear and tended to be quite small, largely due to the sparse population of the high-altitude areas, where all the mines are located. My observations traveling on the ground and conducting interviews indicated that there are few settlements close enough to each mine to be directly affected.

For the survey, I included communities that interacted strongly with the firm to capture the local private politics most clearly. Specifically, I selected communities that either 1) sold land to the firm, 2) had a substantial number of residents who worked for the firm, and/or 3) were acutely affected by environmental externalities that have been attributed to the mine (no objective data exist for environmental impacts, so I based this on perceptions). However, during interviews I probed respondents to learn about actions of the firm outside of this core set of communities. Also, in all cases I interviewed people from larger units (e.g. municipalities) to understand the broader role of the mine in the region. These interviews indicated that the decisions regarding which communities to include in the enclave did not influence the coding of any variables. In other words, I could have extended or reduced the number of communities on the margins, and the patterns of distribution would have been coded in the same way. This is largely because firm behavior was shaped by the closets communities that were best positioned to disrupt the firm.

Below I provide more detail on the communities included in the survey for each mine:

- Porco: There were two major communities near the mine constituting almost all the local population. Other small communities were satellites of these two communities, or were cut off from the mine by mountains (rendering them quite distant by road). The survey included only the two major communities.

- San Carlos: There was a single community located atop the mine that housed the bulk of the affected population. In addition, there was a set of surrounding communities also closely connected to the firm mainly through employment: when the mine opened, people from those areas migrated to the community atop the mine for work but kept homes in their original communities. I included the two of these communities closest to the mine. A set of seven communities had members who were workers. I included the largest of these communities (the others were so small they were practically abandoned; in total, of all communities that sent workers to the firm, I included those that accounted for $80 \%$ of the population). Excluding this most distant community did not change the results of the main quantitative analyses. ${ }^{21}$

- Kori Kollo: I surveyed the two large communities where the mine's operations took place. Both communities sold land to make the operation. There were smaller

\footnotetext{
${ }^{21}$ Compared with Porco, including the more distant communities in San Carlos allows for a more conservative analysis (i.e. biasing towards finding people are unlikely gain from the firm's distributive efforts) as these communities had relatively less contact with the firm.
} 
communities in the surrounding area, but they were largely abandoned during the survey team's visits.

- San Cristobal: I surveyed the three communities located where the mine's operations took place. Other communities were a large distance (over 20KM) from the mine or were satellites of the main three communities.

All enclaves share a set of characteristics. They all are: (1) located at a considerable distance from mid-sized cities (over a one hour drive); (2) areas of high poverty and low educational attainment; (3) communities that have historically lacked basic services like running water; and (4) economies in which most people who do not work for the firm depend on combinations of subsistence agriculture, small-scale mining, and small commerce.

When assessing the comparability of the enclaves, analytically we want to examine the moment in which the firm entered and distinguish it from the changes that occurred once the firm was established. Unfortunately, the series of available snapshots in Table A2 (at 2001, 2012, and 2015 for the survey) has limitations and cannot adequately capture these moments. Therefore, I report the data that I have but also rely on qualitative accounts in the case studies that provide accounts of changes over time to analyze the comparability of the enclaves.

Between Kori Kollo and San Cristobal, the two enclaves had very similar initial conditions when the mines entered. Both were small communities that were dependent on agriculture at the time of the mine's entry. Eventually, both sets of communities in the enclaves grew to similar levels of population (both reached approximately 2,700 people).

Between Porco and San Carlos, the one substantial difference, at the time of the firms' entry, was population. The large population in Porco was due to the presence of cooperatives within the enclave. Therefore, population was directly tied to economic fragmentation in the enclave, raising the question of which variable was really doing the work. In other words, the cross-case comparison may be influenced by the difference in population, which could alter the cost of providing inclusive benefits relative to targeted benefits, rather than social structure. Within-case analysis, however, strongly suggests that population alone cannot account for the outcomes in the cases. First, in Porco, cooperatives and their leaders made it clear that they were not interested in public goods provision, and neither were union leaders. In other words, providing public goods, no matter what the cost, would not have satisfied these key groups. Second, and related, as shown in the Table 2, support for or opposition to the firm was not associated with individual evaluations of social services. Therefore, the counterfactual that the firm was pressured to provide these goods and chose not to due to cost is also not supported. Third, the firm in Porco could have provided inclusive benefits that would have large economies of scale. Therefore, while larger population might influence the cost of healthcare or education, it would not increase the costs of providing benefits that can be delivered easily in densely populated areas, such as supporting industrial development (as the firm initially intended). These actions would have made it relatively inexpensive to provide for and reach large numbers.

Turning to San Carlos, the isolated and small population increased the costs of providing some goods that the firm did supply. For example, to subsidize education and provide agricultural outreach, the firm had to pay for staff to relocate to the community, requiring high 
salaries and housing costs. Thus, it is unlikely that San Carlos selected these public goods because they were inexpensive to deliver. Finally, in San Carlos, groups were demanding social services, and not private goods. Therefore, it would have been difficult for the firm to buy support with private goods. For these reasons, population alone, rather than fragmentation, is an unlikely alternative explanation for the differences between these two cases.

Table A2 provides additional detail regarding the enclaves at points in time when data were available. Note that the difference in the proportion of people in Kori Kollo versus San Cristobal who had a family member working for the mine is somewhat due to the timing of the survey.

Table A2: Basic Features of Enclaves

\begin{tabular}{|c|c|c|c|c|c|c|}
\hline & & $\begin{array}{r}\text { Population } \\
2001 \text { (census) }\end{array}$ & $\begin{array}{r}\text { Population } \\
2012 \text { (census) }\end{array}$ & $\begin{array}{r}\% \text { work in } \\
\text { mining } \\
\text { (survey) }\end{array}$ & $\begin{array}{r}\% \text { with family } \\
\text { member who } \\
\text { works for firm } \\
\text { (survey) }\end{array}$ & $\begin{array}{r}\% \text { with } \\
\text { agricultural } \\
\text { production } \\
\text { (survey) }\end{array}$ \\
\hline \multirow[t]{3}{*}{ Porco } & Community 1 & 1,504 & 2,858 & \multirow{3}{*}{$28 \%$} & \multirow{3}{*}{$40 \%$} & \multirow{3}{*}{$40 \%$} \\
\hline & Community 2 & 1,975 & 5,287 & & & \\
\hline & Total Porco & 3,479 & 8,145 & & & \\
\hline \multirow{5}{*}{ San Carlos } & Community 1 & 96 & 1,007 & \multirow{5}{*}{$29 \%$} & \multirow{5}{*}{$67 \%$} & \multirow{5}{*}{$40 \%$} \\
\hline & Community 2 & 510 & 288 & & & \\
\hline & Community 3 & 129 & 287 & & & \\
\hline & Community 4 & 73 & 98 & & & \\
\hline & $\begin{array}{r}\text { Total San } \\
\text { Carlos }\end{array}$ & 808 & 1,680 & & & \\
\hline \multirow{3}{*}{ Kori Kollo } & Community 1 & 1,817 & 2,029 & \multirow{3}{*}{$25 \%{ }^{22}$} & \multirow{3}{*}{$\begin{array}{r}11 \% \text { ( } 48 \% \text { have } \\
\text { a family } \\
\text { member who } \\
\text { used to work for } \\
\text { the firm) }\end{array}$} & \multirow{3}{*}{$70 \%$} \\
\hline & Community 2 & 871 & 331 & & & \\
\hline & $\begin{array}{r}\text { Total Kori } \\
\text { Kollo }\end{array}$ & 2,688 & 2,360 & & & \\
\hline \multirow{4}{*}{ San Cristobal } & Community 1 & 922 & 1,754 & \multirow{4}{*}{$17 \%$} & \multirow{4}{*}{$68 \%$} & \multirow{4}{*}{$51 \%$} \\
\hline & Community 2 & 232 & 398 & & & \\
\hline & Community 3 & 371 & 676 & & & \\
\hline & $\begin{array}{l}\text { Total San } \\
\text { Cristobal }\end{array}$ & 1,525 & 2,828 & & & \\
\hline
\end{tabular}

${ }^{22}$ At the time of the survey, people were transitioning to working in small-scale mining. These cooperatives did not compete with the firm because they lack the technology required for the type of mineral Kori Kollo exploits. 


\section{SURVEY EXPERIMENT}

Listed in the table below are the values for Figure 5. The effect sizes of the firm offering the services were greater for Porco and Kori Kollo compared with San Carlos and San Cristobal for both goods. ${ }^{23}$

Table A3: "If the [MINING FIRM] [MUNICIPALITY] announced it will undertake a project to improve [community health] [access to water]: would you expect to have access to it?

\begin{tabular}{|l|lcccc|}
\hline \multicolumn{2}{|c}{} & Porco & $\begin{array}{c}\text { San } \\
\text { Carlos }\end{array}$ & Kori Kollo & $\begin{array}{c}\text { San } \\
\text { Cristobal }\end{array}$ \\
\hline \multirow{3}{*}{ Health Care } & Municipality treatment & $87 \%$ & $80 \%$ & $86 \%$ & $90 \%$ \\
\cline { 2 - 6 } & Mining firm treatment & $70 \%$ & $85 \%$ & $61 \%$ & $87 \%$ \\
\cline { 2 - 6 } & p of H: Municipality = Mining Firm & $<0.01$ & 0.20 & $<0.01$ & 0.27 \\
\cline { 2 - 6 } & N & 311 & 320 & 310 & 419 \\
\hline \multirow{5}{*}{ Water } & Municipality treatment & $90 \%$ & $86 \%$ & $89 \%$ & $94 \%$ \\
\cline { 2 - 6 } & Mining firm treatment & $69 \%$ & $88 \%$ & $67 \%$ & $86 \%$ \\
\cline { 2 - 6 } & p of H: Municipality = Mining Firm & $<0.01$ & 0.54 & $<0.01$ & 0.01 \\
\cline { 2 - 6 } & N & 303 & 322 & 315 & 411 \\
\hline
\end{tabular}

\section{Conditional Treatment Effects}

To measure how the firms undertook targeted transfers, I test the conditionality of the effect of the mining firm promising services on active union members versus the rest of the population. Tables A4 and A5, below, show the conditional effects of the survey experiment on active union members and the rest of the population. For Porco, the difference in treatment is statistically significant for the question regarding healthcare, but not for the question regarding water. None of the other cases show statistically significant differences in effects across groups. In San Carlos, there is no treatment effect in the non-union sample for either good: consistent with the argument, non-union members do not believe that the municipality is a more credible service provider than the firm. Yet, for union members, there is a positive effect for the question regarding healthcare (but not for the question regarding water). Therefore, union members believe that they are more likely to gain this service from the firm than from the municipality. The difference in the treatment sizes, however, is not statistically significant, so we cannot reject the hypothesis that union members and non-union members respond to the firm offering the service in the same way. For San Cristobal, there is no treatment effect for the question regarding healthcare for both the union and the non-union samples.

\footnotetext{
${ }^{23}$ ANOVA tests of differences in effect sizes for health and water, respectively, returned the following results: Kori Kollo compared with San Cristobal ( $=734, \mathrm{~F}=16.22, \mathrm{p}<0.01$; $\mathrm{N}=721, \mathrm{~F}=7.39, \mathrm{p}<0.01)$; Kori Kollo compared with San Carlos $(\mathrm{N}=637, \mathrm{~F}=22.71, \mathrm{p}<0.01 ; \mathrm{N}=630, \mathrm{~F}=16.54, \mathrm{p}<0.01)$; Porco compared with San Cristobal $(\mathrm{N}=730$, $\mathrm{F}=7.08, \mathrm{p}<0.01 ; \mathrm{N}=714, \mathrm{~F}=6.11, \mathrm{p}=0.01)$; and Porco compared with $\operatorname{San}$ Carlos $(\mathrm{N}=633, \mathrm{~F}=13.12, \mathrm{p}<0.01 ; \mathrm{N}=623$, $\mathrm{F}=15.01, \mathrm{p}<0.01)$.
} 
Table A4: Access to Health Program ${ }^{24}$

\begin{tabular}{|c|c|c|c|c|c|}
\hline & & Porco & $\begin{array}{r}\text { San } \\
\text { Carlos }\end{array}$ & Kori Kollo & $\begin{array}{r}\text { San } \\
\text { Cristobal }\end{array}$ \\
\hline \multirow[t]{5}{*}{ Non-Union } & Municipality & $89 \%$ & $81 \%$ & $86 \%$ & $89 \%$ \\
\hline & Mining firm treatment & $67 \%$ & $82 \%$ & $61 \%$ & $85 \%$ \\
\hline & $\mathrm{p}$ of H: Municipality= Mining Firm & $<0.00$ & 0.89 & $<0.00$ & 0.20 \\
\hline & $\mathrm{N}$ of group & 296 & 294 & 295 & 359 \\
\hline & Difference & $-22 \%$ & $1 \%$ & $-25 \%$ & $-5 \%$ \\
\hline \multirow[t]{5}{*}{ Union } & Municipality & $67 \%$ & $79 \%$ & $88 \%$ & $97 \%$ \\
\hline & Mining firm treatment & $94 \%$ & $94 \%$ & $57 \%$ & $96 \%$ \\
\hline & p of H: Municipality = Mining Firm & 0.00 & 0.04 & 0.05 & 0.84 \\
\hline & $\mathrm{N}$ of group & 31 & 92 & 31 & 78 \\
\hline & Difference & $27 \%$ & $15 \%$ & $-31 \%$ & $-1 \%$ \\
\hline \multirow{3}{*}{$\begin{array}{l}\text { Difference } \\
\text { in Groups }\end{array}$} & Difference in Treatment & $-50 \%$ & $-15 \%$ & $6 \%$ & $-4 \%$ \\
\hline & $\mathrm{F}$ of $\mathrm{H}$ : Difference in treatment $=0$ & 10.06 & 2.45 & 0.16 & 0.22 \\
\hline & $\mathrm{p}$ of $\mathrm{H}$ : Difference in treatment $=0$ & $<0.01$ & 0.12 & 0.69 & 0.64 \\
\hline
\end{tabular}

Table A5: Access to Water Program

\begin{tabular}{|c|c|c|c|c|c|}
\hline & & Porco & $\begin{array}{r}\text { San } \\
\text { Carlos } \\
\end{array}$ & $\begin{array}{r}\text { Kori } \\
\text { Kollo } \\
\end{array}$ & $\begin{array}{r}\text { San } \\
\text { Cristobal } \\
\end{array}$ \\
\hline \multirow[t]{5}{*}{ Non-Union } & Municipality & $90 \%$ & $86 \%$ & $89 \%$ & $93 \%$ \\
\hline & Mining firm treatment & $67 \%$ & $85 \%$ & $67 \%$ & $85 \%$ \\
\hline & p of H: Municipality= Mining Firm & $<0.01$ & 0.96 & $<0.00$ & 0.03 \\
\hline & $\mathrm{N}$ of group & 296 & 294 & 295 & 359 \\
\hline & Difference & $-23 \%$ & $0 \%$ & $-22 \%$ & $-8 \%$ \\
\hline \multirow[t]{5}{*}{ Union } & Municipality & $91 \%$ & $86 \%$ & $88 \%$ & $100 \%$ \\
\hline & Mining firm treatment & $88 \%$ & $94 \%$ & $69 \%$ & $89 \%$ \\
\hline & $\mathrm{p}$ of $\mathrm{H}$ : Municipality= Mining Firm & 0.83 & 0.23 & 0.22 & 0.02 \\
\hline & $\mathrm{N}$ of group & 31 & 92 & 31 & 78 \\
\hline & Difference & $-3 \%$ & $8 \%$ & $-19 \%$ & $-11 \%$ \\
\hline \multirow{3}{*}{$\begin{array}{r}\text { Difference } \\
\text { in Groups }\end{array}$} & Difference in Treatment & $-20.1 \%$ & $-7.9 \%$ & $-3.2 \%$ & $3.3 \%$ \\
\hline & $\mathrm{F}$ of $\mathrm{H}$ : Difference in treatment $=0$ & 1.66 & 0.9 & 0.04 & 0.17 \\
\hline & $\mathrm{p}$ of H: Difference in treatment $=0$ & 0.20 & 0.34 & 0.84 & 0.68 \\
\hline
\end{tabular}

${ }^{24}$ Active union members are defined as people who list their occupation as mining and who participate in private sector union meetings at least once a year. 
In addition to asking respondents if they believed they would have access to services, the survey experiment also asked whether people believed the project would be completed and of good quality. The figures below show the responses to these additional questions. Note that, for the assessment of quality, the results are largely the same as for access. For Porco and Kori Kollo, telling people the mining firm instead of the municipality offered the benefit led to a statistically significant decrease in the likelihood of their believing the service would be of "good quality," while for San Carlos and San Cristobal there was no effect. However, for the question on delivery, there is one difference: people living near Porco believe that the mining firm is just as likely to deliver the good as is the municipality. Congruent with the theory, the results in Porco suggest that, in fragmented enclaves, people believe the firm will provide the benefits it promises, but the general public does not believe that they will gain access to these benefits.

\section{Figure A1: Expectations for Quality}

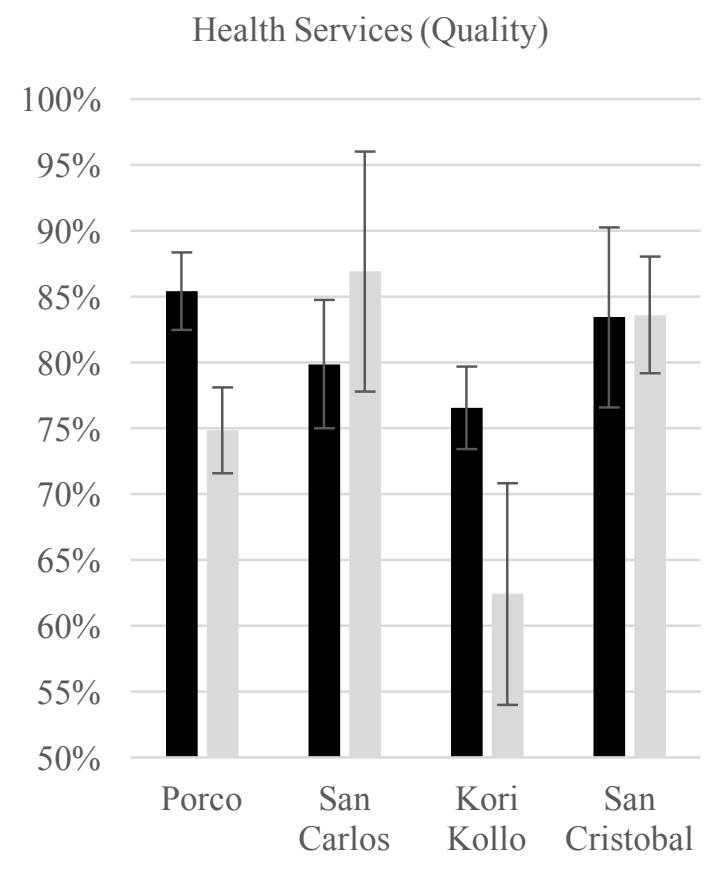

- Municipality Mining Firm
Drinking Water (Quality)

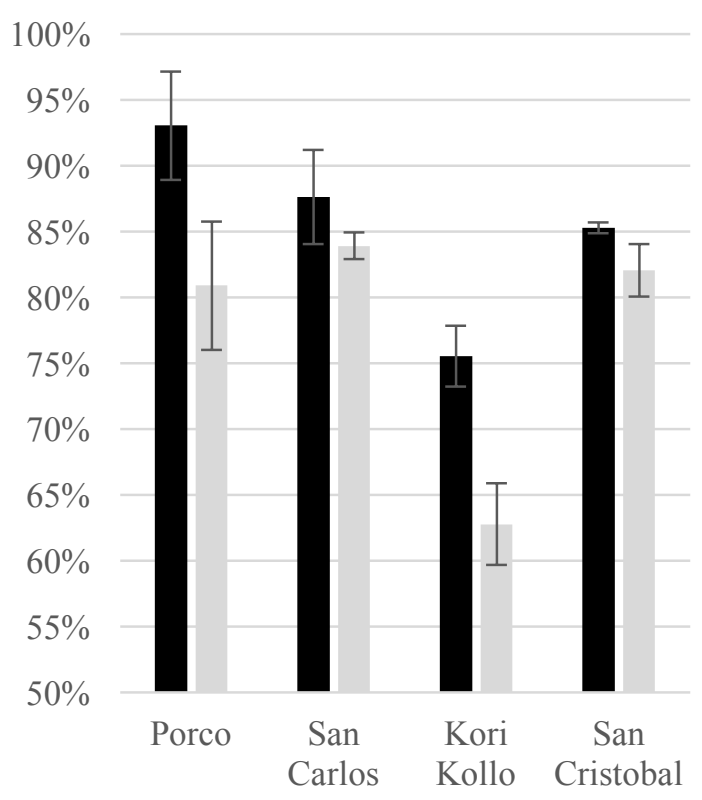

- Municipality Mining Firm 
Figure A2: Expectations for Completed Project

Health Services (completed)

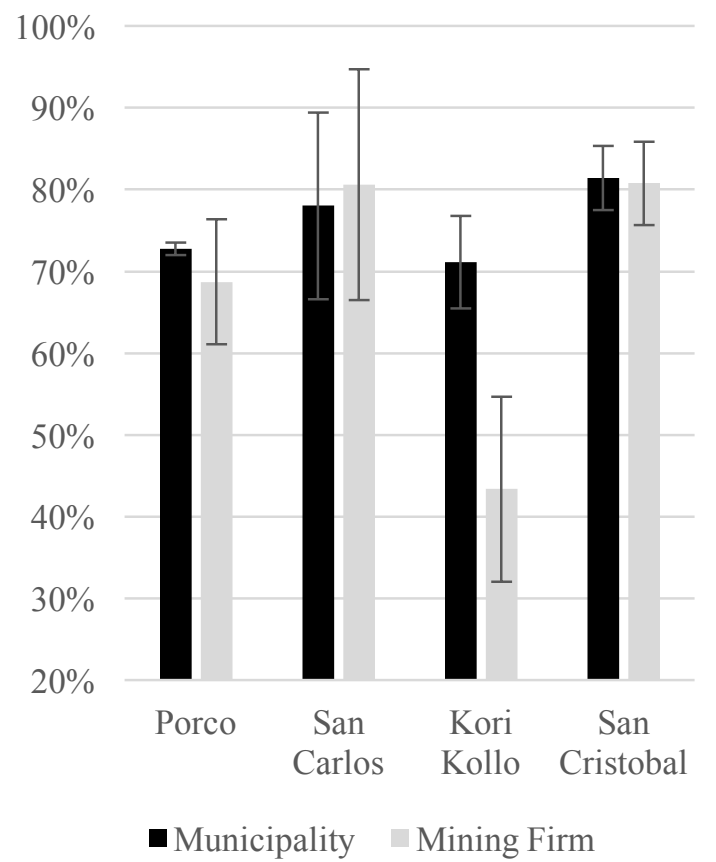

Drinking Water (completed)

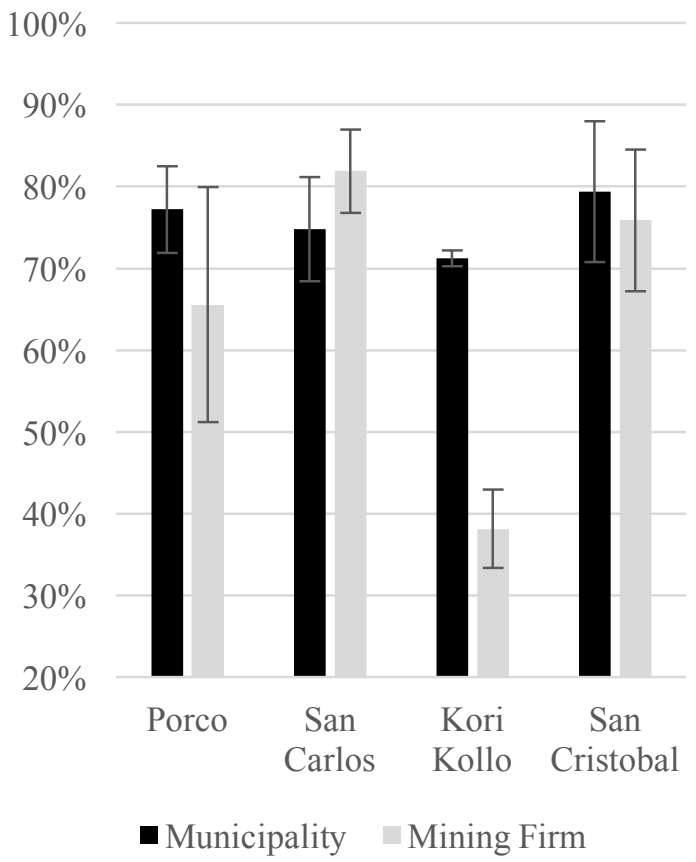

One possibility that arises from these additional questions is that people have distinct expectations of the firm completing a project, rather than merely providing access to that service. Given the fact that the survey was conducted as Kori Kollo was in its closing phase, one concern is that people did not expect Kori Kollo to deliver any goods due its closing phase, rather than not expecting to gain access were the firm to deliver a good (see also Table A10). To more precisely test the hypothesis that the mines in cohesive enclaves engage in more inclusive service delivery, and those in fragmented enclaves do not, I ran a series of regression analyses examining the treatment effect of the mine offering the good while controlling for responses to the questions regarding quality and delivery. I use OLS models to ease interpretation (the results are the same using logit models). The results, in Tables A7 and A8, show that for Kori Kollo and Porco the effect sizes are smaller but are still statistically significant and negative (there is no effect for the cases with cohesive enclaves, San Carlos and San Cristobal). Thus, the cases differ not only on the expectation that firms will deliver benefits to the enclave, but also on the inclusiveness of service provision. 
Table A6: Expectations of Access to Health Services Controlling for Delivery and Quality

\begin{tabular}{lllll}
\hline & $(\mathrm{A} 1)$ & (A2) & (A4) & (A3) \\
& Porco & San Carlos & Kori Kollo & San Cristobal \\
\hline Mining Firm Treatment & $-0.143^{* * *}$ & 0.0191 & $-0.102^{* *}$ & -0.0126 \\
& $(0.0441)$ & $(0.0375)$ & $(0.0425)$ & $(0.0275)$ \\
Quality & $0.447^{* * *}$ & $0.403^{* * *}$ & $0.422^{* * *}$ & $0.419^{* * *}$ \\
& $(0.0828)$ & $(0.103)$ & $(0.0725)$ & $(0.0844)$ \\
Delivery & 0.105 & $0.371^{* * *}$ & $0.312^{* * *}$ & $0.178^{* *}$ \\
& $(0.0642)$ & $(0.0897)$ & $(0.0667)$ & $(0.0731)$ \\
Constant & $0.440^{* * *}$ & $0.171^{* *}$ & $0.286^{* * *}$ & $0.391^{* * *}$ \\
& $(0.0718)$ & $(0.0856)$ & $(0.0560)$ & $(0.0693)$ \\
Observations & & & & \\
R-squared & 251 & 238 & 249 & 340 \\
\hline
\end{tabular}

OLS models. Robust standard errors in parentheses $* * * \mathrm{p}<0.01, * * \mathrm{p}<0.05, * \mathrm{p}<0.1$

Table A7: Expectations of Access to Water Holding Controlling for Delivery and Quality

\begin{tabular}{lcccc}
\hline & $(\mathrm{A} 5)$ & $(\mathrm{A})$ & $(\mathrm{A})$ & $(\mathrm{A})$ \\
& Porco & San Carlos & Kori Kollo & San Cristobal \\
\hline Mining Firm Treatment & $-0.107^{* * *}$ & 0.0272 & $-0.121^{* * *}$ & -0.0368 \\
& $(0.0391)$ & $(0.0361)$ & $(0.0462)$ & $(0.0261)$ \\
Quality & $0.533^{* * *}$ & $0.342^{* * *}$ & $0.446^{* * *}$ & $0.337^{* * *}$ \\
& $(0.0899)$ & $(0.0954)$ & $(0.0722)$ & $(0.0703)$ \\
Delivery & $0.176^{* * *}$ & $0.260^{* * *}$ & $0.210^{* * *}$ & $0.245^{* * *}$ \\
& $(0.0624)$ & $(0.0788)$ & $(0.0620)$ & $(0.0553)$ \\
Constant & $0.294^{* * *}$ & $0.358^{* * *}$ & $0.377^{* * *}$ & $0.439^{* * *}$ \\
& $(0.0763)$ & $(0.0883)$ & $(0.0638)$ & $(0.0689)$ \\
& & & & \\
Observations & 246 & 231 & 230 & 321 \\
R-squared & 0.428 & 0.344 & 0.469 & 0.406 \\
\hline
\end{tabular}

OLS models. Robust standard errors in parentheses $* * * \mathrm{p}<0.01, * * \mathrm{p}<0.05, * \mathrm{p}<0.1$

\section{ALTERNATIVE MEASURES OF FIRM CONTRIBUITONS}

The analysis of the survey experiment focused on two goods, water and healthcare, and, as a result, is limited to the particular experiences people had with these goods. Heeding the warnings of those who argue that the good one studies influences one's findings in distributive politics, ${ }^{25}$ I chose goods that have distinct characteristics. It is possible to target healthcare precisely by making it available only to certain people (such as families of workers). It is more

\footnotetext{
${ }^{25}$ Kramon, Eric, Daniel N Posner. "Who Benefits from Distributive Politics? How the Outcome One Studies Affects the Answer One Gets." Perspectives on Politics 11, 02, 2013
} 
difficult to target water infrastructure: once built, a system has large network effects and is accessible to most people.

To more generally understand how people, perceive firms' distribution of benefits, I also asked people to evaluate, on a scale of 1 to 7, the effectiveness of the mining firm and the municipality in "solving the community's problems". The results, in Table A9, are largely consistent with the survey experiment. For Kori Kollo and Porco, the mean response was higher for the municipality than for the mining firm, congruent with the conclusion that, in these cases, the state was indeed the more important actor in local governance. By contrast, for San Cristobal, there was no significant difference between evaluations of the firm and the state. Finally, for San Carlos the response was higher for the mining firm than for the municipality, demonstrating the dominance of the firm in this case.

Table A8: On a scale of 1-7, 1 is not effective and 7 is very effective, how effective do you believe the following organizations and institutions to be in resolving the problems of the community:

\begin{tabular}{|ccccc|}
\hline & N & Municipality & Mining firm & p-value on H: No difference in means \\
\hline Porco & \multirow{2}{*}{299} & $\begin{array}{c}3.88 \\
(0.10)\end{array}$ & $\begin{array}{c}2.95 \\
(0.10)\end{array}$ & $<0.01$ \\
\hline $\begin{array}{c}\text { San } \\
\text { Carlos }\end{array}$ & \multirow{2}{*}{279} & $\begin{array}{c}3.61 \\
(0.10)\end{array}$ & $\begin{array}{c}4.95 \\
(0.09)\end{array}$ & $<0.01$ \\
\hline $\begin{array}{c}\text { Kori } \\
\text { Kollo }\end{array}$ & \multirow{2}{*}{299} & $\begin{array}{c}3.62 \\
(0.09)\end{array}$ & $\begin{array}{c}2.63 \\
(0.09)\end{array}$ & $<0.01$ \\
\hline $\begin{array}{c}\text { San } \\
\text { Cristobal }\end{array}$ & \multirow{2}{*}{396} & $\begin{array}{c}4.37 \\
(0.07)\end{array}$ & $\begin{array}{c}4.34 \\
(0.08)\end{array}$ & 0.76 \\
\hline
\end{tabular}

Standard error in parentheses. 
As an additional test, the survey asked people about their expectations for the mining firms (although not the municipalities) in providing gifts, employment, and public infrastructure projects, were the firm to expand production. The wording of this question responds to one of the limits of the main analysis, which is that the questions about receiving benefits may be sensitive to the period in which we conducted the survey (when commodity prices were dropping and production decreasing in many of the mines). To partially mitigate this problem, I once again built on the work of Calvo and Murillo (2012) and measured people's expectations for gaining a set of benefits were the mine to increase production. During fieldwork, I found that many people were highly sensitive to commodity prices and aware of their importance for the viability of the mines and therefore were likely able to adjust their expectations accordingly. The questions measured three different types of goods: handouts, employment, and investment in public works. The results, shown in Table A8, are also consistent with the questions regarding health care and water. Responses concerning both handouts and public works were higher in San Cristobal and San Carlos, compared with Kori Kollo and Porco.

Table A9: If the mining company discovered more minerals and prices increased, making the mine more profitable and the company increase its investment, how likely (1-7) would the company be to provide you with...?

\begin{tabular}{|c|c|c|c|c|}
\hline & Porco & $\begin{array}{c}\text { San } \\
\text { Carlos } \\
\end{array}$ & $\begin{array}{l}\text { Kori } \\
\text { Kollo } \\
\end{array}$ & $\begin{array}{c}\text { San } \\
\text { Cristobal } \\
\end{array}$ \\
\hline $\begin{array}{l}\text { Assistance, such as school supplies, or a gift for } \\
\text { your children }\end{array}$ & $\begin{array}{c}3.56 \\
(0.32)\end{array}$ & $\begin{array}{c}5.00 \\
(0.15)\end{array}$ & $\begin{array}{c}3.57 \\
(0.01)\end{array}$ & $\begin{array}{c}4.40 \\
(0.04)\end{array}$ \\
\hline $\begin{array}{l}\text { A job or a contract to provide services to the } \\
\text { company }\end{array}$ & $\begin{array}{c}3.05 \\
(0.12)\end{array}$ & $\begin{array}{c}4.61 \\
(0.22)\end{array}$ & $\begin{array}{c}3.67 \\
(0.02)\end{array}$ & $\begin{array}{c}3.85 \\
(0.12)\end{array}$ \\
\hline $\begin{array}{l}\text { Investments in public works required by the } \\
\text { community }\end{array}$ & $\begin{array}{c}3.44 \\
(0.22)\end{array}$ & $\begin{array}{c}4.72 \\
(0.22)\end{array}$ & $\begin{array}{c}3.55 \\
(0.06)\end{array}$ & $\begin{array}{c}4.32 \\
(0.02)\end{array}$ \\
\hline
\end{tabular}

Standard error in parenthesis 


\section{SUPPORT AND OPPOSITION TO THE FIRM}

\section{Table A10: Description of Variables}

\begin{tabular}{|c|c|c|}
\hline Variable & Question & Coding \\
\hline Support for Firm & $\begin{array}{l}\text { Do you oppose or support the [MINING } \\
\text { COMPANY]? }\end{array}$ & $\begin{array}{l}1 \text { = Strongly Oppose firm } \\
2 \\
3 \\
4 \text { = Neither Support nor Oppose } \\
5 \\
6 \\
7 \text { = Strongly Support firm } \\
.=\text { Do not know / No Response }\end{array}$ \\
\hline \multirow[t]{4}{*}{$\begin{array}{l}\text { Social Services } \\
\text { (constructed from } \\
\text { sum of these four } \\
\text { variables) }\end{array}$} & $\begin{array}{l}\text { How does the quality of schools in your } \\
\text { community compare to other schools in } \\
\text { the municipality? }\end{array}$ & $\begin{array}{l}1=\text { Better } \\
0=\text { About the Same } \\
-1=\text { Worse } \\
=\text { Do not know } / \text { No Response }\end{array}$ \\
\hline & $\begin{array}{l}\text { Have the schools in your community } \\
\text { improved or gotten worse in the past } 5 \\
\text { years? }\end{array}$ & $\begin{array}{l}1=\text { Improved } \\
0=\text { Have not changed } \\
-1=\text { Have gotten worse } \\
.=\text { Do not know / No Response } \\
\end{array}$ \\
\hline & $\begin{array}{l}\text { Has the quality of health services } \\
\text { improved or become worse in the past } 5 \\
\text { years? }\end{array}$ & $\begin{array}{l}1=\text { Improved } \\
0=\text { Have not changed } \\
-1=\text { Have gotten worse } \\
.=\text { Do not know } / \text { No Response }\end{array}$ \\
\hline & $\begin{array}{l}\text { How does the quality of health services } \\
\text { in this community compare to those of } \\
\text { nearby communities? }\end{array}$ & $\begin{array}{l}1=\text { Better } \\
0=\text { About the Same } \\
-1=\text { Worse } \\
.=\text { Do not know } / \text { No Response }\end{array}$ \\
\hline Company Family & $\begin{array}{l}\text { Does anyone in your family work for the } \\
\text { [MINING COMPANY]? }\end{array}$ & $\begin{array}{l}1=\text { Yes } \\
0=\text { No } \\
.=\text { Don't Know / No Response }\end{array}$ \\
\hline Environment & $\begin{array}{l}\text { Compared with other communities in the } \\
\text { area, how would you rate environmental } \\
\text { quality (la situación medio ambiente)? }\end{array}$ & $\begin{array}{l}1=\text { Much worse } \\
2 \\
3 \\
4=\text { The same } \\
5 \\
6 \\
7=\text { Much Better } \\
\text { = Do not know } / \text { No Response }\end{array}$ \\
\hline Agriculture & $\begin{array}{l}\text { Do you or anyone in your household } \\
\text { cultivate agricultural products, livestock? }\end{array}$ & $\begin{array}{l}1=\text { Yes } \\
0=\text { No } \\
=\text { Don't Know / No Response }\end{array}$ \\
\hline Individual Claims & $\begin{array}{l}\text { Have you solicited help or presented a } \\
\text { petition to [MINING COMPANY] in the } \\
\text { past } 12 \text { months? }\end{array}$ & $\begin{array}{l}1=\text { Yes } \\
0=\text { No } \\
=\text { Don't Know / No Response }\end{array}$ \\
\hline Household Assets & $\begin{array}{l}\text { The index was built upon questions } \\
\text { regarding whether the household had: a } \\
\text { refrigerator, vehicle, motorcycle, } \\
\text { computer, house in the country, or house } \\
\text { in the city. }\end{array}$ & $\begin{array}{l}\text { For each sample, I conducted a } \\
\text { principal components analysis } \\
\text { and used the first principal } \\
\text { component. }\end{array}$ \\
\hline
\end{tabular}

${ }^{26}$ Using the first component from a principal component analysis yields similar results as simply adding the values of the variables. 
Table A11: Summary Statistics

\begin{tabular}{|c|c|c|c|c|c|c|c|c|c|}
\hline & & Support & $\begin{array}{l}\text { Social } \\
\text { Services }\end{array}$ & $\begin{array}{l}\text { Company } \\
\text { Family } \\
\end{array}$ & Env. & Agr. & $\begin{array}{l}\text { Ind. } \\
\text { Demands } \\
\end{array}$ & Gender & $\begin{array}{l}\text { House. } \\
\text { Assets } \\
\end{array}$ \\
\hline \multirow{5}{*}{$\begin{array}{l}\overrightarrow{0} \\
\stackrel{0}{0}\end{array}$} & $\mathrm{~N}$ & 321 & 297 & 327 & 325 & 327 & 327 & 327 & 327 \\
\hline & mean & 4.19 & 0.00 & 0.40 & 3.08 & 0.40 & 0.12 & 0.50 & 0 \\
\hline & s.d. & 2.03 & 1.00 & 0.49 & 1.4 & 0.49 & 0.33 & 0.50 & 0.72 \\
\hline & $\min$ & 1 & -2.8 & 0 & 1 & 0 & 0 & 0 & -0.93 \\
\hline & $\max$ & 7 & 1.4 & 1 & 7 & 1 & 1 & 1 & 1.49 \\
\hline \multirow{5}{*}{ 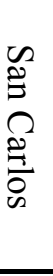 } & $\mathrm{N}$ & 322 & 304 & 335 & 330 & 333 & 334 & 335 & 334 \\
\hline & mean & 5.45 & 0.00 & 0.67 & 4.38 & 0.41 & 0.14 & 0.51 & 0 \\
\hline & s.d. & 1.50 & 1.00 & 0.47 & 1.43 & 0.49 & 0.34 & 0.50 & 0.68 \\
\hline & $\min$ & 1 & -4.4 & 0 & 1 & 0 & 0 & 0 & -0.99 \\
\hline & $\max$ & 7 & 1.5 & 1 & 7 & 1 & 1 & 1 & 1.28 \\
\hline \multirow{5}{*}{ 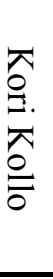 } & $\mathrm{N}$ & 315 & 312 & 326 & 323 & 326 & 326 & 326 & 325 \\
\hline & mean & 3.17 & 0.00 & 0.11 & 3.06 & 0.70 & 0.09 & 0.50 & 0 \\
\hline & s.d. & 1.82 & 1.00 & 0.32 & 1.53 & 0.46 & 0.29 & 0.50 & 0.69 \\
\hline & $\min$ & 1 & -2.4 & 0 & 1 & 0 & 0 & 0 & -0.95 \\
\hline & $\max$ & 7 & 2.0 & 1 & 7 & 1 & 1 & 1 & 1.52 \\
\hline \multirow{5}{*}{ 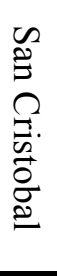 } & $\mathrm{N}$ & 423 & 391 & 437 & 422 & 437 & 436 & 437 & 437 \\
\hline & mean & 5.02 & 0.00 & 0.68 & 4.26 & 0.51 & 0.09 & 0.50 & 0 \\
\hline & s.d. & 1.45 & 1.00 & 0.47 & 1.2 & 0.50 & 0.29 & 0.50 & 0.69 \\
\hline & $\min$ & 1 & -2.6 & 0 & 1 & 0 & 0 & 0 & -0.95 \\
\hline & $\max$ & 7 & 1.29 & 1 & 7 & 1 & 1 & 1 & 1.52 \\
\hline
\end{tabular}


Table A12 below contains the same regression analyses that were displayed in Tables 2 $\& 3$ in the main text. To determine if the Social Service coefficients are different in Models 1 and 2, or Models 3 and 4, I combine the two samples and interact all variables with an indicator for each mine, then test the equivalence of the coefficient for Social Services interacted with the dummy variable for each sample. We can reject the null hypothesis that the coefficients are the same for Models 1 and $2(\mathrm{~F}=14.30, \mathrm{p}<0.001)$, as well as Models 3 and $4(\mathrm{~F}=6.29, \mathrm{p}=0.01)$. An alternative, shown in Table A13, is to pool the samples and interact a dummy for the cohesive enclave. The results are substantively the same.

Note that the coefficients on the control variables are largely congruent with the case analyses, going beyond the analysis of Social Services. There is a large coefficient on Company Family for Porco, providing additional evidence that the key divide in this enclave was between workers for the firm and others, mainly cooperative workers (and, as is evident in the Agriculture coefficient, those who remained in agriculture). Neither of these variables are significant for San Carlos, suggesting that these divides are less salient.

In the cases of Kori Kollo and San Cristobal, the differences in the results for Company Family are less informative, as the numbers of people who continue to work for the firm at the time of the survey in Kori Kollo were small (Table A2). There is a significant coefficient on Company Family for San Cristobal, which shows that there was indeed a difference in support across those who worked for the mine and those who did not. However, as the case analysis reveals, the interests of both groups were channeled through the community assembly and the union that kept social ties. Congruent with the case studies, in Kori Kollo there is a positive coefficient on Individual Claims, consistent with the qualitative evidence that in this case the firm maintained support from families with which it engaged in individual exchange relationships. 
Table A12: Services and Support

\begin{tabular}{|c|c|c|c|c|}
\hline & (1) & (2) & (3) & (4) \\
\hline & Porco & San Carlos & Kori Kollo & San Cristobal \\
\hline \multirow[t]{2}{*}{ Social Services } & -0.0291 & $0.286 * *$ & -0.0744 & $0.114^{* *}$ \\
\hline & $(0.0333)$ & $(0.0693)$ & $(0.0666)$ & $(0.0258)$ \\
\hline \multirow[t]{2}{*}{ Company Family } & $0.769 * *$ & 0.298 & -0.173 & $0.443 *$ \\
\hline & $(0.165)$ & $(0.196)$ & $(0.279)$ & $(0.201)$ \\
\hline \multirow[t]{2}{*}{ Environment } & $0.265 * *$ & $0.130 * *$ & $0.353 * *$ & $0.169 * *$ \\
\hline & $(0.0760)$ & $(0.0111)$ & $(0.00530)$ & $(0.0108)$ \\
\hline \multirow[t]{2}{*}{ Agriculture } & $-0.296 * *$ & -0.0971 & $-0.508 * *$ & -0.192 \\
\hline & $(0.0342)$ & $(0.166)$ & $(0.0288)$ & $(0.108)$ \\
\hline \multirow[t]{2}{*}{ Individual Claims } & -0.655 & -0.0779 & $0.497 * *$ & -0.214 \\
\hline & $(0.406)$ & $(0.129)$ & $(0.101)$ & $(0.201)$ \\
\hline \multirow[t]{2}{*}{ Gender } & $-0.296^{*}$ & 0.161 & $-0.495 * *$ & $0.353 * *$ \\
\hline & $(0.146)$ & $(0.148)$ & $(0.0699)$ & $(0.129)$ \\
\hline \multirow[t]{2}{*}{ Household Assets } & $0.622 * *$ & 0.438 & $0.213 * * *$ & 0.0128 \\
\hline & $(0.196)$ & $(0.276)$ & $(0.0317)$ & $(0.0817)$ \\
\hline \multirow[t]{2}{*}{ Constant } & $3.450 * *$ & $4.597 * *$ & $2.674 * *$ & $3.990 * *$ \\
\hline & $(0.497)$ & $(0.226)$ & $(0.116)$ & $(0.221)$ \\
\hline Observations & 293 & 289 & 298 & 377 \\
\hline R-squared & 0.147 & 0.158 & 0.120 & 0.072 \\
\hline
\end{tabular}


Table A13: Pooled Samples with Interactions

\begin{tabular}{|c|c|c|c|}
\hline & $\begin{array}{c}(1) \\
\text { Combined } \\
\text { Porco \& San Carlos }\end{array}$ & $\begin{array}{c}\text { (2) } \\
\text { Combined } \\
\text { Kori Kollo \& } \\
\text { San Cristobal } \\
\end{array}$ & $\begin{array}{c}\text { (3) } \\
\text { Pool of All Four } \\
\text { Samples }\end{array}$ \\
\hline Social Services & $\begin{array}{l}-0.0122 \\
(0.0123)\end{array}$ & $\begin{array}{l}-0.0420 \\
(0.0570)\end{array}$ & $\begin{array}{l}-0.0297 \\
(0.0234)\end{array}$ \\
\hline Company Family & $\begin{array}{l}0.511 * * \\
(0.141)\end{array}$ & $\begin{array}{c}0.265 \\
(0.227)\end{array}$ & $\begin{array}{l}0.590 * * \\
(0.175)\end{array}$ \\
\hline Environment & $\begin{array}{l}0.185 * * \\
(0.0434)\end{array}$ & $\begin{array}{l}0.261 * * \\
(0.0401)\end{array}$ & $\begin{array}{l}0.230 * * \\
(0.0333)\end{array}$ \\
\hline Agriculture & $\begin{array}{l}-0.162 * \\
(0.0739)\end{array}$ & $\begin{array}{c}-0.333 * * \\
(0.0962)\end{array}$ & $\begin{array}{c}-0.415 * * \\
(0.113)\end{array}$ \\
\hline Individual Claims & $\begin{array}{l}-0.349 \\
(0.219)\end{array}$ & $\begin{array}{c}0.137 \\
(0.170)\end{array}$ & $\begin{array}{l}-0.0873 \\
(0.182)\end{array}$ \\
\hline Gender & $\begin{array}{l}-0.0601 \\
(0.121)\end{array}$ & $\begin{array}{l}-0.0182 \\
(0.203)\end{array}$ & $\begin{array}{l}-0.0584 \\
(0.137)\end{array}$ \\
\hline Household Assets & $\begin{array}{l}0.519 * * \\
(0.161)\end{array}$ & $\begin{array}{c}0.120 \\
(0.0618)\end{array}$ & $\begin{array}{l}0.280 * * \\
(0.0954)\end{array}$ \\
\hline San Carlos*Social Services & $\begin{array}{l}0.268 * * \\
(0.0833)\end{array}$ & & \\
\hline San Carlos Dummy & $\begin{array}{l}0.784 * * \\
(0.265)\end{array}$ & & \\
\hline San Cristobal*Social Services & & $\begin{array}{l}0.165 * * \\
(0.0609)\end{array}$ & \\
\hline San Cristobal Dummy & & $\begin{array}{l}1.368 * * \\
(0.127)\end{array}$ & \\
\hline Cohesive $^{27} *$ Social Services & & & $\begin{array}{l}0.229 * * \\
(0.0525)\end{array}$ \\
\hline Cohesive & & & $\begin{array}{l}0.936 * * \\
(0.323)\end{array}$ \\
\hline Constant & $\begin{array}{c}3.599 * * \\
(0.326)\end{array}$ & $\begin{array}{l}2.572 * * \\
(0.0835)\end{array}$ & $\begin{array}{c}3.113 * * \\
(0.282)\end{array}$ \\
\hline $\begin{array}{l}\text { Observations } \\
\text { R-squared }\end{array}$ & $\begin{array}{c}582 \\
0.215\end{array}$ & $\begin{array}{c}675 \\
0.316\end{array}$ & $\begin{array}{l}1,257 \\
0.252\end{array}$ \\
\hline OLS regres & $\begin{array}{l}\text { ootstrapped standard error } \\
* * \mathrm{p}<0.01, * \mathrm{p}<0.05\end{array}$ & ustered by commu & \\
\hline
\end{tabular}


Table A14: Robust Standard Errors Clustered at Community Level ${ }^{28}$

\begin{tabular}{lllll}
\hline & $(1)$ & $(2)$ & $(3)$ & $(4)$ \\
& Porco & San Carlos & Kori Kollo & San Cristobal \\
\hline \multirow{3}{*}{ Social Services } & -0.0212 & $0.246^{*}$ & -0.0772 & $0.125^{* * *}$ \\
& $(0.0405)$ & $(0.0794)$ & $(0.0664)$ & $(0.0109)$ \\
Company Family & 0.731 & 0.0491 & -0.176 & 0.455 \\
& $(0.227)$ & $(0.268)$ & $(0.270)$ & $(0.176)$ \\
Environment & 0.243 & $0.104^{* * *}$ & $0.354^{* *}$ & $0.172^{* * *}$ \\
& $(0.102)$ & $(0.00403)$ & $(0.0101)$ & $(0.0168)$ \\
Agriculture & $-0.236^{* *}$ & 0.0728 & $-0.509^{* *}$ & -0.192 \\
& $(0.00797)$ & $(0.145)$ & $(0.0388)$ & $(0.0874)$ \\
Ind. Claims & -0.665 & -0.0863 & 0.510 & -0.217 \\
& $(0.565)$ & $(0.0722)$ & $(0.152)$ & $(0.167)$ \\
M/F & -0.298 & 0.106 & $-0.495^{*}$ & $0.350^{*}$ \\
& $(0.203)$ & $(0.121)$ & $(0.0590)$ & $(0.110)$ \\
Household Assets & 0.622 & 0.301 & 0.213 & 0.0144 \\
& $(0.268)$ & $(0.237)$ & $(0.0435)$ & $0.0847)$ \\
Constant & $3.782^{*}$ & $5.090^{* * *}$ & $2.682^{* *}$ & $4.057^{* * *}$ \\
& $(0.435)$ & $(0.0957)$ & $(0.106)$ & $(0.173)$ \\
Observations & & & & \\
R-squared & 293 & 289 & 298 & 377 \\
\hline
\end{tabular}

Robust standard errors, clustered at the community-level, in parentheses. Community dummies included. $* * * \mathrm{p}<0.01, * * \mathrm{p}<0.05, * \mathrm{p}<0.1$

\footnotetext{
${ }^{28}$ Following the same approach as described above (interacting all variables with dummies for the enclave a in pooled model), we can reject the hypothesis that coefficients on Social Services are the same for Porco and San Carlos $(\mathrm{F}=10.78, \mathrm{p}=0.02)$ and Kori Kollo and San Cristobal $(\mathrm{F}=14.31, \mathrm{p}=0.02)$.
} 
Table A15: Ordered Logit Models ${ }^{29}$

\begin{tabular}{lcccc}
\hline & $(1)$ & $(2)$ & $(3)$ & $(4)$ \\
& Porco & San Carlos & Kori Kollo & San Cristobal \\
\hline \multirow{3}{*}{ Social Services } & & & & \\
& -0.0237 & $0.418^{* *}$ & -0.0789 & $0.157^{* *}$ \\
Company Family & $(0.0163)$ & $(0.134)$ & $(0.0753)$ & $(0.0108)$ \\
& $0.738^{* *}$ & 0.466 & -0.0757 & $0.630^{* *}$ \\
Environment & $(0.157)$ & $(0.424)$ & $(0.202)$ & $(0.100)$ \\
& $0.262^{* *}$ & $0.163^{* *}$ & $0.397^{* *}$ & $0.218^{* *}$ \\
Agriculture & $(0.0436)$ & $(0.0134)$ & $(0.0358)$ & $(0.00827)$ \\
& $-0.273^{* *}$ & -0.0386 & $-0.539^{* *}$ & $-0.296^{* *}$ \\
Individual Claims & $(0.0575)$ & $(0.204)$ & $(0.0257)$ & $(0.0859)$ \\
& -0.625 & 0.0295 & $0.501^{* *}$ & -0.234 \\
Gender & $(0.369)$ & $(0.265)$ & $(0.0660)$ & $(0.145)$ \\
& -0.222 & 0.258 & $-0.439^{* *}$ & $0.443^{* *}$ \\
Household Assets & $(0.146)$ & $(0.146)$ & $(0.0285)$ & $(0.0691)$ \\
& $0.572^{* *}$ & 0.602 & $0.209^{* *}$ & -0.0125 \\
Constant cut1 & $(0.203)$ & $(0.593)$ & $(0.0117)$ & $(0.0655)$ \\
& $-0.989^{* *}$ & $-3.067^{* *}$ & $-0.272^{* *}$ & $-3.225^{* *}$ \\
Constant cut2 & $(0.284)$ & $(0.649)$ & $(0.0452)$ & $(0.246)$ \\
& -0.488 & $-2.255^{* *}$ & $0.165^{*}$ & $-1.800^{* *}$ \\
Constant cut3 & $(0.480)$ & $(0.723)$ & $(0.0663)$ & $(0.156)$ \\
& 0.0694 & $-1.401^{* *}$ & $0.802^{* *}$ & $-0.682^{* *}$ \\
Constant cut4 & $(0.375)$ & $(0.325)$ & $(0.150)$ & $(0.142)$ \\
& $0.759^{*}$ & -0.0456 & $2.016^{* *}$ & $0.752^{* *}$ \\
Constant cut5 & $(0.354)$ & $(0.175)$ & $(0.243)$ & $(0.121)$ \\
& $1.719^{* *}$ & $1.111^{* *}$ & $2.929^{* *}$ & $1.762^{* *}$ \\
Constant cut6 & $(0.396)$ & $(0.212)$ & $(0.354)$ & $(0.0555)$ \\
& $2.656^{* *}$ & $2.133^{* *}$ & $3.775^{* *}$ & $2.990^{* *}$ \\
Observations & $(0.637)$ & $(0.202)$ & $(0.589)$ & $(0.0926)$ \\
& & & & \\
& 293 & 289 & 298 & 377 \\
\hline
\end{tabular}

Bootstrapped standard errors clustered by community. ${ }^{* *} \mathrm{p}<0.01,{ }^{*} \mathrm{p}<0.05$

\footnotetext{
${ }^{29}$ Again, pooling samples from each set of mines, interacting all variables with a dummy for the cohesive mine, and testing the equivalence of the coefficients, allows us to reject the null hypothesis that the coefficient of Social Services is the same for Porco as San Carlos $(\mathrm{F}=11.86, \mathrm{p}<0.01)$ that Kori Kollo and San Cristobal are the same $(\mathrm{F}=4.36, \mathrm{p}=0.04)$. Pooling the samples and only interacting a dummy variable for each mine with Social Services also produces statistically significant interaction terms. Results are substantively similar using cluster robust standard errors.
} 


\section{COMPARAISON OF FIRM POLICIES}

The main text contains a brief overview of the policies of the parent multinationals of each mine. To augment these data, I collected data from all publically available documents containing information about the policies of the parent companies of the firms. I use these data to determine if there were major differences in the adoption of policies that could explain variation. When the parent company changed, I use with the earliest date for which evidence for the policy is adopted during the period that the mine was owned by a particular firm. In other words, if a multinational adopted a policy in the year 2000 and then purchased the mine in 2005,2005 is listed as the start date.

I do not presume that the adoption of these externally facing policies and structures are necessarily indicative of the actual practices of the firms (that I measure using other data). Rather, these categories are the types of indicators used in theories emphasizing global norms (e.g. Dashwood 2012).

Table A16: Year of Adoption and Communication of Policies

\begin{tabular}{|l|l|l|l|l|}
\hline & $\begin{array}{l}\text { Porco } \\
\text { (start year } \\
\mathbf{2 0 0 5})\end{array}$ & $\begin{array}{l}\text { San Carlos } \\
\text { (start year } \\
\mathbf{1 9 9 9 )}\end{array}$ & $\begin{array}{l}\text { Kori Kollo } \\
\text { (start year } \\
\mathbf{1 9 9 0}\end{array}$ & $\begin{array}{l}\text { San } \\
\text { Cristobal } \\
\text { (start year } \\
\text { 1997) }\end{array}$ \\
\hline Release CSR Report & 2010 & 2010 & 2003 & 2006 \\
\hline $\begin{array}{l}\text { Specialized Division for Community } \\
\text { Development }\end{array}$ & 2006 & 2001 & 1991 & 1999 \\
\hline $\begin{array}{l}\text { Public Reporting of Community } \\
\text { Development }\end{array}$ & 2010 & 2009 & 2005 & 2006 \\
\hline $\begin{array}{l}\text { Standards for Community Development } \\
\text { Spending on Community Development } \\
\text { Reported (at level of multinational) }\end{array}$ & 2010 & 2010 & 2005 & 2009 \\
\hline $\begin{array}{l}\text { Publically adopted "sustainable } \\
\text { development" in reporting }\end{array}$ & 2010 & 2014 & 2005 & $\begin{array}{l}\text { Never } \\
\text { Adopted }\end{array}$ \\
\hline $\begin{array}{l}\text { ICMM Membership } \\
\text { Reporting using GRI Guidelines }\end{array}$ & 2012 & $\begin{array}{l}\text { Never } \\
\text { Adopted }\end{array}$ & 2001 & 2004 \\
\hline Join Global Compact & 2010 & 2013 & 2005 & $\begin{array}{l}\text { Never } \\
\text { Adopted }\end{array}$ \\
\hline
\end{tabular}

